Note

\title{
TRIPPING ON THE THRESHOLD: FEDERAL COURTS' FAILURE TO OBSERVE CONTROLLING STATE LAW UNDER THE FEDERAL ARBITRATION ACT
}

\author{
CHARLES DAVANT IV
}

\begin{abstract}
INTRODUCTION
For almost a century, attorneys have debated the role federal law should play in the enforcement of private arbitration agreements. ${ }^{1}$ Proponents of a nationalized arbitration law argue that states are too reluctant to enforce private arbitration agreements. They argue that the benefits of arbitration-speed, efficiency, and privacy-will not be realized without a strong national policy in favor of arbitration. ${ }^{2}$ Critics of a nationalized arbitration law, on the other hand, argue that nationalization leaves too little room for state lawmaking. They argue that a national arbitration policy prevents states from enacting important laws for the protection of contracting parties. ${ }^{3}$
\end{abstract}

Copyright (C) 2001 by Charles Davant IV.

1. ian R. MACNEIL, American Arbitration Law: Reformation, NationalizaTION, INTERNATIONALIZATION 84 (1992) (noting that the impetus to nationalize arbitration law began as early as 1918).

2. 1 Martin Domke, Domke on Commercial Arbitration § 4:04 (1996); David P. Pierce, The Federal Arbitration Act: Conflicting Interpretations of Its Scope, 61 U. CIN. L. REV. 623, 651 (1992) (arguing that the Arbitration Act should be read expansively, notwithstanding federalism concerns, because of the "overwhelming benefits of arbitration"); Henry C. Strickland, The Federal Arbitration Act's Interstate Commerce Requirement: What's Left for State Arbitration Law?, 21 HOFSTRA L. REV. 385, 460 (1992) (noting that expansive interpretation of the Arbitration Act may be "justified by the statute's judicial history and beneficial to the [Act's] goal of expeditious arbitration enforcement").

3. See, e.g., Jean R. Sternlight, Panacea or Corporate Tool?: Debunking the Supreme Court's Preference for Binding Arbitration, 74 WASH. U. L.Q. 637, 641 (1996) ("Congress did not intend to enforce arbitration agreements that had been foisted on ignorant consumers, and it did not intend to prevent states from protecting weaker parties."); Traci L. Jones, Note, State Law of Contract Formation in the Shadow of the Federal Arbitration Act, 46 DUKE L.J. 651, 677 
In this debate, the proponents of nationalized arbitration have fared better than the critics. They persuaded Congress in 1925 to enact the Federal Arbitration Act, ${ }^{4}$ a statute that makes arbitration agreements enforceable in the federal courts. ${ }^{5}$ More recently, they persuaded the United States Supreme Court to use the Arbitration Act to effectively nationalize the law of arbitration. At their behest, the Court has held that federal law governs virtually any issue in any dispute in any forum that implicates arbitration in any way. ${ }^{6}$ Faced with a long line of nationalist Supreme Court decisions, critics of nationalization quite understandably have been discouraged. ${ }^{7}$

But even as the critics complain that the Court has become hopelessly solicitous of the national policy in favor of arbitration, the Court has quietly delivered them a victory. In 1987, in Perry v. Tho$m a s,{ }^{8}$ the Supreme Court indicated that state law, not federal law, governs the threshold question of whether parties agreed to submit their disputes to arbitration. ${ }^{9}$ Ordinary state law principles applicable to all contracts determine whether a valid arbitration agreement exists between the parties. ${ }^{10}$

This Note argues that the federalist aspect of Perry has gone unnoticed. ${ }^{11}$ Writers continue to lump Perry together with the Court's

(1996) ("The broad scope of the FAA [Federal Arbitration Act], combined with the U.S. Supreme Court's interpretation of its preemptive effect, has severely restricted the ability of states to regulate arbitration agreements.").

4. Ch. 213, 43 Stat. 883 (1925) (codified as amended at 9 U.S.C. $\S ~ 1-16,201-208$ (1994)).

5. The Act states that

A written provision in any maritime transaction or a contract evidencing a transaction involving commerce to settle by arbitration a controversy thereafter arising out of such contract or transaction, or the refusal to perform the whole or any part thereof, or an agreement in writing to submit to arbitration an existing controversy arising out of such a contract, transaction, or refusal, shall be valid, irrevocable, and enforceable, save upon such grounds as exist at law or in equity for the revocation of any contract.

9 U.S.C. $\$ 2$ (1994).

6. See infra notes $36-41$ and accompanying text.

7. See, e.g., Sternlight, supra note 3, at 641 (stating that the Supreme Court has been seduced by the "myth" that the Arbitration Act was intended to apply in state as well as federal courts); Jones, supra note 3, at 677-78 (criticizing the nationalist reading of the Arbitration Act).

8. 482 U.S. 483 (1987).

9. Id. at 492 n.9.

10. Id.

11. Perry may be an early, unnoticed bellwether of the Rehnquist Court's "new federalism," which gained notoriety in the celebrated federalism decisions of the 1990s. See, e.g., Alden v. Maine, 527 U.S. 706, 712 (1999) (holding that Congress lacks the power to subject nonconsenting states to suit in state court); College Sav. Bank v. Fla. Prepaid Postsecondary Educ. Expense Bd., 527 U.S. 666, 691 (1999) (holding that Congress lacks the power to abrogate state 
nationalist arbitration decisions, ${ }^{12}$ and lower federal courts have failed to heed the federalist teaching of Perry. ${ }^{13}$ In practice, courts have not observed controlling state contract law. Instead, they have continued to invent "federal contract law" to resolve the threshold question of whether parties agreed to submit to arbitration. Because the federalist aspect of Perry has gone unnoticed, the critics of nationalization have been denied the fruits of a rare victory.

Part I describes the process of arbitration and the Supreme Court's nationalization of arbitration law. It also introduces Perry $v$. Thomas. Part II describes a typical fact pattern from construction law for which Perry should provide the rule of decision. It critiques a recent federal decision in which the court unintentionally "tripped on the threshold" by failing to apply state law to the question of whether an arbitration agreement existed. ${ }^{14}$ Part III considers some reasons

sovereign immunity from trademark infringement lawsuits in federal court); Printz v. United States, 521 U.S. 898, 935 (1997) (holding that Congress lacks the power to require state officers to execute federal laws); United States v. Lopez, 514 U.S. 549, 567-68 (1995) (limiting Congress's Commerce Clause power on federalism grounds); New York v. United States, 505 U.S. 144, 149 (1992) (holding that the Tenth Amendment limits Congress's power to require states to take ownership of nuclear waste).

12. See infra note 49 and accompanying text.

13. See infra Part III.

14. Even the United States Supreme Court may be prone to neglect its own precedents by failing to apply state contract law. In EEOC v. Waffle House, Inc., 193 F.3d 805 (4th Cir. 1999), cert. granted, 121 S. Ct. 1401 (2001) — a case before the Court at the time of this writing - the Court is considering "whether an employee's agreement to arbitrate employment-related disputes with an employer bars the Equal Employment Opportunity Commission, as plaintiff in an enforcement action against the employer, from obtaining victim-specific remedies for discrimination against the employee, such as backpay, reinstatement, and damages." Brief for Petitioner at I, EEOC v. Waffle House, Inc., 193 F.3d 805 (4th Cir. 1999), cert. granted, 121 S. Ct. 1401 (2001) (No. 99-1823), available at 2001 WL 603394, at *I. The Court apparently is not considering the more fundamental question of whether the employee consented to the arbitration agreement under South Carolina law, even though this question was hotly debated in the appeals court below. Compare Waffle House, Inc., 193 F.3d at 808-09 (holding that a valid agreement existed), with id. at 813-15 (King, J., dissenting) (arguing that no agreement existed). In their briefs to the Supreme Court, neither party raised the threshold question of whether a valid arbitration agreement existed. See Brief for Petitioner, Waffle House, 193 F.3d 805, available at 2001 WL 603394; Brief for Respondent, Waffle House, 193 F.3d 805, available at 2001 WL 799217. Similarly, the Justices at oral argument appeared to assume that a valid arbitration agreement existed. Transcript of Oral Argument at 23, Oct. 10, 2001, appeal of EEOC v. Waffle House, Inc., 193 F.3d 805 (4th Cir. 1999), cert. granted, 121 S. Ct. 1401 (2001) (No. 99-1823), available at $2001 \mathrm{WL} 1262396$ (reporting that a Justice asked the attorney for the government whether the Arbitration Act embodies a preference for arbitration "where an arbitration agreement has been entered into, as it was here") (emphasis added).

The parties' reluctance to argue the threshold question before the Supreme Courtand the Justices' apparent reluctance to consider it—is unfortunate, since the Fourth Circuit's decision appears to be a particularly egregious example of a federal court failing to consider con- 
federal courts routinely make this mistake. It explains that the $\mathrm{Su}$ preme Court's jurisprudence in this area is difficult for lawyers to understand, that judges tend to follow precedents that were themselves wrongly decided, and that courts are persuaded to compel parties to arbitrate for policy reasons. Part IV argues as a normative matter that state law, not federal law, should govern determinations of whether parties agreed to arbitrate. Specifically, the application of state law protects the parties' expectations and preserves state sovereignty. Part V demonstrates that federal courts' continued treatment of the threshold question as one of federal law makes it likely that litigants will face different substantive rules depending on whether they litigate in state or federal court. Lower courts' error therefore creates incentives for litigants to forum shop. ${ }^{15}$

\section{A BRIEF History OF ARBITRATION LAW}

\section{A. Nationalization}

Arbitration is a process that allows parties voluntarily to refer their disputes to an impartial third person, an arbitrator, selected by them to determine the parties' rights and liabilities. ${ }^{16}$ Arbitrators' decisions are subject to very limited grounds of review, and thus are final and enforceable in the same manner as a court judgment. ${ }^{17} \mathrm{Be}-$ cause arbitration can be faster, more confidential, and less expensive

\footnotetext{
trolling state law in deciding whether an arbitration agreement exists. In deciding the threshold question, the appeals court ignored the district court's factual findings and considered no South Carolina precedent, instead treating the panel's own assumptions about corporate practices as dispositive of the question of whether an agreement to arbitrate had been formed. Waffle House, 193 F.3d at 808-09. The dissenting judge, by contrast, deferred to the district court's factual findings and applied contract principles from three South Carolina decisions in finding that no arbitration agreement existed. Waffle House, Inc., 193 F.3d at 814, 816 (King, J., dissenting) (citing Prescott v. Farmers Tel. Coop., 516 S.E.2d 923 (S.C. 1999); Player v. Chandler, 382 S.E.2d 891 (S.C. 1989); and Carolina Amusement Co. v. Conn. Nat'l Life Ins. Co., 437 S.E.2d 122 (S.C. Ct. App. 1993)).

15. This Note will not address cases decided under the Miller Act, 40 U.S.C. $§ \S 270 a-270 f$ (1994). The Miller Act applies when the federal government is the contract owner. United States Fid. \& Guar. Co. v. West Point Constr. Co., 837 F.2d 1507, 1508 (11th Cir. 1988). In such cases, the Act limits the rights and remedies of the parties in a manner that provides special protection for federal subcontractors. Id. To protect federal subcontractors, federal courts show extra skepticism toward general incorporation by reference to arbitration clauses in Miller Act cases. Id.; J.S. \& H. Constr. Co. v. Richmond County Hosp. Auth., 473 F.2d 212, 215-17 (5th Cir. 1973).

16. 1 DOMKE, supra note $2, \S 1: 01$.

17. MACNEIL, supra note 1 , at 7 .
} 
than litigation, persons planning business transactions often agree in advance that they will forego litigation and submit to arbitration any disputes that may arise from the parties' future dealings. ${ }^{18}$

Sometimes a party who signed an agreement to arbitrate future disputes regrets that decision. After a dispute arises, the party may believe that it would benefit from the delays inherent in litigation or that lay arbitrators will not take its legal defenses seriously. ${ }^{19}$ Under the state common law and arbitration codes that were in effect at the start of the twentieth century, that party could escape arbitration quite easily. The party had the right to revoke the arbitration agreement, thereby depriving the arbitrators of their power to make an award. ${ }^{20}$ The revoking party then could bring a judicial action on the underlying dispute. ${ }^{21}$ Because pre-dispute arbitration agreements were effectively unenforceable, the benefits of arbitration were not fully realized. ${ }^{22}$ Differences between the states' arbitration laws created horizontal forum shopping problems. ${ }^{23}$

18. 1 DomKe, supra note 2, § 1:01 (citing Gates v. Ariz. Brewing Co., 95 P.2d 49, 50 (Ariz. 1939)); see also MACNEIL, supra note 1, at 3 ("For a good many years the commercial and financial world has felt increasingly beleaguered by the costs of litigation.").

19. Arbitrators need not have any legal training. Paul D. Carrington \& Paul H. Haagen, Contract and Jurisdiction, 1996 SUP. CT. REV. 331, 344. Nor must they resolve disputes in compliance with the parties' legal rights. $I d$. at 345 .

20. MACNEIL, supra note 1 , at 20. To be effective, a revocation had to occur before an award was rendered. Id.; Linda R. Hirshman, The Second Arbitration Trilogy: The Federalization of Arbitration Law, 71 VA. L. REV. 1305, 1310-11 nn.27-28 (1985).

21. MACNEIL, supra note 1 , at 20.

22. Some members of Congress believed that the lackluster enforcement of arbitration agreements by state courts resulted from the jealous guard courts keep over their jurisdiction. H.R. REP. NO. 96-68, at 1-2 (1924):

[The need for the Federal Arbitration Act] arises from ... the jealousy of the English courts for their own jurisdiction .... This jealousy survived for so long a period that the principle became firmly embedded in the English common law and was adopted with it by the American courts. The courts have felt that the precedent was too strongly fixed to be overturned without legislative enactment ....

23. One proponent of the Federal Arbitration Act, referring to the handling of disputes in New York, told Congress:

Where they are involved as to New York State jurisdiction pure and simple, we press for arbitration, and we can get it because there is no difficulty about it; but the moment the Hudson River separates us, over in New Jersey, and when it is a Jersey case against a New York case, we can not do so.

A Bill Relating to Sales and Contracts to Sell in Interstate Commerce; and A Bill to Make Valid and Enforceable Written Provisions or Agreements for Arbitration of Disputes Arising out of Contracts, Maritime Transactions, or Commerce Among the States or Territories or with Foreign Nations: Hearing on S. 4213 and S. 4214 Before a Subcomm. of the S. Comm. on the Judiciary, 67th Cong., 4th Sess. 4 (1923) [hereinafter Hearing] (statement of Charles L. Bernheimer, President, American Arbitration Association). 
Congress sought to remedy these defects in 1925 by enacting the Federal Arbitration Act. ${ }^{24}$ The Act makes pre-dispute arbitration agreements "evidencing a transaction involving commerce ... valid, irrevocable, and enforceable, save upon such grounds as exist at law or in equity for the revocation of any contract." ${ }^{25}$ The Act requires courts to stay court proceedings or compel participation in an arbitration proceeding upon being satisfied that the issue involved is referable to arbitration under such an agreement. ${ }^{26}$

During the first three or four decades of the Arbitration Act's existence, the Supreme Court (and everyone else) understood that it was a procedural statute applicable only in the federal courts. ${ }^{27}$ Most people accepted that the Act's sponsors in Congress intended for its scope to be quite narrow, applying only to cases in admiralty and in "interstate commerce," as that term was defined before the New Deal. ${ }^{28}$ In short, the Act was considered part of a "truly federal-state system of arbitration law." 29

The view that the Arbitration Act supplemented, rather than supplanted, state law began to lose favor in the 1950s. In 1956, the Supreme Court held in Bernhardt v. Polygraphic Co. of America ${ }^{30}$ that state arbitration law is substantive, not procedural. ${ }^{31}$ Curiously, this modest holding had the unintended effect of requiring lower courts to nationalize arbitration law. It forced courts down a path of logic that led away from the Arbitration Act's conceptual origins. If state arbitration law was substantive, then state arbitration law should apply in federal courts in diversity cases under Erie Railroad Co. v. Tomp-

24. Act of Feb. 12, 1925, Pub. L. No. 68-401, 43 Stat. 883 (codified as amended at 9 U.S.C. $\S \S 1-16(1994))$.

25. 9 U.S.C. $\$ 2(1994)$.

26. Id. §§ 3-4.

27. MACNEIL, supra note 1, at 83,114-15 (noting that the lack of opposition to the Arbitration Act's enactment is "explicable only if everyone aware of the proposed legislationwhich included, inter alia, all members of the [American Bar Association] who bothered to read their mail-understood it to be limited to the federal courts").

28. An advocate of the Federal Arbitration Act, Charles L. Bernheimer, told Congress in 1923 that the federal legislation would follow "the lines of the New York arbitration law, applying it to the fields wherein there is Federal jurisdiction. These fields are in admiralty and in foreign and interstate commerce." Hearing, supra note 23, at 2. No congressman in 1923 could know how far "interstate commerce" would extend after the Supreme Court's "switch in time" paved the way for the New Deal.

29. MACNEIL, supra note 1 , at 83.

30. 350 U.S. 198 (1956).

31. Id. at $202-05$. 
kins, ${ }^{32}$ unless federal law preempted it. As everyone knew, the Federal Arbitration Act-not state arbitration law-applied in federal courts in diversity cases. Therefore, the lower courts held, the Federal Arbitration Act must preempt state arbitration law. ${ }^{33}$ In 1967, less than ten years after lower courts first grappled with this syllogism, the Supreme Court endorsed it in Prima Paint Corp. v. Flood \& Conklin Manufacturing Co. ${ }^{34}$ This decision transformed the Arbitration Act into a national regulatory statute, superseding state law under the Supremacy Clause of the federal Constitution. As one critic later noted, "[ $\mathrm{t}]$ his mutation from a system in which state law was the foundation and federal law but an important adjunct had occurred with singularly little debate and with virtually no democratic input." ${ }^{35}$

In subsequent decades, the Supreme Court completed the nationalization of arbitration law. ${ }^{36}$ The Court held that the Act creates a body of federal substantive law $;^{37}$ that the Act requires courts to interpret arbitration agreements mindful of the "liberal federal policy favoring arbitration agreements," notwithstanding any state substantive or procedural laws to the contrary ${ }^{38}$ that the Act preempts state law hostile to arbitration; ${ }^{39}$ that the Act applies in both state and federal courts; ${ }^{40}$ and that the Act renders enforceable any arbitration agreement that Congress could regulate without exceeding the practically negligible limits on its interstate commerce power. ${ }^{41}$

32. 304 U.S. 64 (1938).

33. Robert Lawrence Co. v. Devonshire Fabrics, Inc., 271 F.2d 402, $406-07$ (2d Cir. 1959) ("[C]ongress intended by the Arbitration Act to create a new body of federal substantive law affecting the validity and interpretation of arbitration agreements... [This is] national law equally applicable in state or federal courts.").

34. 388 U.S. 395, 404-05 (1967).

35. MACNEIL, supra note 1 , at 139.

36. Hirshman, supra note 20, at 1305-06 ("The Court has put its imprimatur on a federalization of arbitration law comparable to its role in the dramatic evolution of labor arbitration in the early 1960's.").

37. Moses H. Cone Mem'l Hosp. v. Mercury Constr. Corp., 460 U.S. 1, 24 (1983). The Arbitration Act does not create any independent federal question jurisdiction under 28 U.S.C. $\S 1331$ or otherwise. $I d$. at $25 \mathrm{n} .32$. Section 4 provides for an order compelling arbitration only when the federal district court would have jurisdiction over a suit on the underlying dispute; hence, there must be diversity of citizenship or some other independent basis for federal jurisdiction before an order can issue. Id.

38. Id. at 24.

39. Doctor's Assocs., Inc. v. Casarotto, 517 U.S. 681, 687-88 (1996).

40. Southland Corp. v. Keating, 465 U.S. 1, 11-12 (1984).

41. Perry v. Thomas, 482 U.S. 483, 490 (1987). The Supreme Court's transformation of the Federal Arbitration Act into a national regulatory statute did not occur without criticism. Justice O'Connor accused the Court majority of abandoning "all pretense of ascertaining congres- 
Despite the Supreme Court's march toward nationalism, none of its decisions squarely faced the question of whether federal or state law governs the threshold issue of the parties' consent to a valid arbitration agreement. But lower courts interpreted the Supreme Court's nationalist, pro-arbitration rhetoric to mean that state law had no role in disputes over arbitration agreements. ${ }^{42}$ In determining whether a party had agreed to submit a dispute to arbitration, lower courts purported to apply "federal contract law" or "generally accepted principles of contract law." 43

\section{B. Perry v. Thomas: A Revolution Unrecognized}

It was against this background that the Supreme Court in 1987 decided Perry v. Thomas. ${ }^{44}$ In Perry, the former employee of a securi-

sional intent with respect to the Federal Arbitration Act, building instead, case by case, an edifice of its own creation." Allied-Bruce Terminix Cos. v. Dobson, 513 U.S. 265, 283 (1995) (O'Connor, J., concurring). Justice Stevens stated that the Court "has effectively rewritten the statute to give it a pre-emptive scope that Congress certainly did not intend." Perry, 482 U.S. at 493 (Stevens, J., dissenting); see also Circuit City Stores, Inc. v. Adams, 532 U.S. 135, 121 S. Ct. 1302, 1315 (2001) (Stevens, J., dissenting) ("[N]either the history of the drafting of the original bill by the ABA, nor the records of the deliberations in Congress during the years preceding the ultimate enactment of the Act in 1925, contains any evidence that the proponents of the legislation intended it to apply to agreements affecting employment."); id. at 1318-22 (Souter, J., dissenting) ("The Court has no good reason, therefore, to reject a reading of 'engaged in' as an expression of intent to legislate to the full extent of the commerce power over employment contracts."); Southland, 465 U.S. at 19-21 (Stevens, J., dissenting) ("Surely the general language of the Arbitration Act that arbitration agreements are valid does not mean that all such agreements are valid irrespective of their purpose or effect."); William N. Eskridge, Jr. \& John Ferejohn, Super Statutes, 50 DUKE L.J. 1215, 1260 (2001) ("[T]he Supreme Court has construed the [Arbitration Act] broadly, with a breadth sweeping well beyond the statute's plain meaning and the probable expectations of its framers in 1925."). Professors Carrington and Haagen have suggested that the Supreme Court is "so absorbed in matters of seemingly greater public moment that its members have failed to attune themselves to the values and the realities of private law." Carrington \& Haagen, supra note 19, at 338. Moreover, they have called the opinion of the Court in Southland an "extraordinarily disingenuous" manipulation of the history of the 1925 Act. Id. at 380.

42. Consider, for example, Genesco, Inc. v. T. Kakiuchi \& Co., 815 F.2d 840 (2d Cir. 1987):

In enacting the federal Arbitration Act, Congress created national substantive law governing questions of the validity and the enforceability of arbitration agreements under its coverage. Hence whether Genesco is bound by the arbitration clause of the sales confirmation forms is determined under federal law, which comprises generally accepted principles of contract law.

Id. at 845 (citations omitted).

43. See, e.g., Neal v. Hardee's Food Sys. Inc., 918 F.2d 34, 37 \& n.5 (5th Cir. 1990) (holding that federal law governed the question of whether separate agreements should be construed together to determine if an arbitration agreement has been formed); Genesco, 815 F.2d at 845 (binding a party to an arbitration agreement printed on the back of a sales confirmation form).

44. 482 U.S. 483 (1987). 
ties brokerage firm sued his former employer and two coworkers, alleging that he was owed commissions on the sale of securities. ${ }^{45} \mathrm{Al}$ though the parties had signed an agreement to arbitrate future disputes, the plaintiff sought to avoid arbitration on the ground that the California Labor Code authorized him to maintain an action for the commissions, without regard to the existence of any private agreement to arbitrate. ${ }^{46}$ The Court rejected his argument. ${ }^{47}$ It held that the Federal Arbitration Act was in "unmistakable conflict" with the California statute, so the state statute had to give way. ${ }^{48}$

Because the Perry Court held that federal law preempted a state law, scholars tend to lump the decision together with the nationalist decisions that preceded it. For example, one scholar has referred to the "ringing march-to-the-federal-flag tone of cases like Moses $\mathrm{H}$. Cone Memorial Hospital v. Mercury Constr. Corp. (U.S. 1983), Southland Corp. v. Keating (U.S. 1984), Dean Witter Reynolds, Inc. v. Byrd (U.S. 1985), and Perry v. Thomas (U.S. 1987)." Another scholar included Perry in the "trilogy of opinions" by the Supreme Court that sharply narrowed the role of state arbitration law. ${ }^{50}$

Despite this conventional wisdom, Perry is better described as a federalist departure from its predecessors. Although Perry's result and tone may seem nationalist (it quotes extensively from its nationalist predecessors), ${ }^{51}$ the decision's meaning is far more nuanced. Perry was the first Supreme Court decision to indicate (albeit in dicta) that under the Federal Arbitration Act, federal and state courts should apply ordinary state contract principles to determine whether an agreement to arbitrate is valid, revocable, or enforceable:

We note, however, the choice-of-law issue that arises when defenses such as Thomas' so-called "standing" and unconscionability arguments are asserted. In instances such as these, the text of [Federal Arbitration Act] $\S 2$ provides the touchstone for choosing between state-law principles and the principles of federal common law envi-

\footnotetext{
45. Id. at $484-85$.

46. Id. at 486 .

47. Id. at 491-92.

48. Id. at 491.

49. MACNEIL, supra note 1, at 154 (italics added) (footnotes omitted).

50. The other two decisions were Southland Corp. v. Keating, 465 U.S. 1 (1984), and Moses H. Cone Memorial Hospital v. Mercury Construction Corp., 460 U.S. 1, 24 (1983). Jones, supra note 3 , at 651 .

51. Perry, 482 U.S. at 489-91 (citing Moses H. Cone, Southland, and Mitsubishi Motors Corp. v. Soler Chrysler-Plymouth, Inc., 473 U.S. 614 (1985)).
} 
sioned by the passage of that statute: An agreement to arbitrate is valid, irrevocable, and enforceable, as a matter of federal law, "save upon such grounds as exist at law or in equity for the revocation of any contract." Thus state law, whether of legislative or judicial origin, is applicable if that law arose to govern issues concerning the validity, revocability, and enforceability of contracts generally. ${ }^{52}$

Federal law preempts state contract law only when the applicable state principles take their "meaning precisely from the fact that a contract to arbitrate is at issue" specifically hostile to arbitration.

This federalist reading of Perry was implicitly confirmed in a subsequent decision. In Mastrobuono v. Shearson Lehman Hutton, Inc. ${ }^{54}$ the Supreme Court cited precedent from Illinois, the forum state and place where the disputed contract was executed, and from New York, the state designated in the contract's choice-of-law clause, in interpreting a contract. ${ }^{55}$ In a later decision, First Options of Chicago, Inc. v. Kaplan ${ }^{56}$ the Court explicitly confirmed this reading of Perry. In that decision, the Court stated: "When deciding whether the parties agreed to arbitrate a certain matter (including arbitrability), courts generally... should apply ordinary state-law principles that govern the formation of contracts." ${ }^{57}$ The Court then noted that Illinois provided the law relevant to that dispute. ${ }^{58}$

52. Id. at $492 \mathrm{n} .9$ (citations omitted). Justice Marshall's opinion for the Court was joined by Chief Justice Rehnquist and Justices Brennan, White, Blackmun, Powell, and Scalia. Id. at 483. Justices Stevens and O'Connor dissented. Id. at 483.

53. Id. at 493 n.9; see also Doctor's Assocs., Inc. v. Casarotto, 517 U.S. 681, 687-88 (1996) (holding that any state law that "places arbitration agreements in a class apart from 'any contract,' and singularly limits their validity" is preempted by federal law).

54. 514 U.S. 52 (1995).

55. Id. at 63 .

56. 514 U.S. 938,944 (1995).

57. Id.

58. Id. In the years since 1987, only a handful of lower federal courts have recognized this federalist feature of Perry. See, e.g., Progressive Cas. Ins. Co. v. C.A. Reaseguradora Nacional de Venez., 991 F.2d 42, 46 (2d Cir. 1993) (noting that, although the Arbitration Act preempts state law that treats arbitration agreements differently from any other contracts, it also "preserves general principles of state contract law as rules of decision on whether the parties have entered into an agreement to arbitrate"” (quoting Cook Chocolate Co. v. Salomon, Inc., 684 F. Supp. 1177, 1182 (S.D.N.Y. 1988))); W.M. Schlosser Co. v. Sch. Bd., 980 F.2d 253, 258-59 (4th Cir. 1992) (holding that federal courts cannot order parties to arbitrate if there is no valid arbitration agreement and that state law governs whether a valid arbitration agreement has been formed); Cione v. Foresters Equity Servs., Inc., 68 Cal. Rptr. 2d 167, 171 (Cal. Ct. App. 1997) (holding that, even if one of the parties contends that the Arbitration Act applies to their agreement to arbitrate, the Act does not apply until the existence of an enforceable arbitration 
The federalist reading of Perry is wholly consistent with recent Supreme Court jurisprudence in other areas. Beginning in the late 1980s, the Rehnquist Court embarked on a much-remarked "new federalism" program, reviving federalism-based limits on Congress's power under the Commerce Clause and Section 5 of the Fourteenth Amendment. ${ }^{59}$ The Rehnquist Court also construed some federal statutes narrowly, mindful of federalism concerns. ${ }^{60}$ Perry thus can be seen as a harbinger of the Court's new states' rights campaign.

Perry's instruction that courts should apply ordinary state contract law to the threshold question of whether parties agreed to arbitrate should be significant to critics of a nationalized arbitration policy for several reasons. First, it means that courts must stop employing a presumption in favor of arbitration when deciding whether parties agreed to arbitrate. ${ }^{61}$ Second, it means that state contract principles that render certain types of agreements unenforceable - such as unconscionable contracts - can invalidate arbitration agreements, notwithstanding federal arbitration law. ${ }^{62}$ Third, it abolishes the "federal common law" of contract that federal courts were fashioning - in contravention of the federalist principles underlying Erie Railroad Co. v. Tompkins ${ }^{63}$ - to govern the threshold question of whether the parties agreed to arbitrate..$^{64}$ Fourth, it means that litigants can no longer forum shop to profit from advantageous rules of law. ${ }^{65}$ These consequences of applying state law are described in Parts IV and V.

\section{Federal Courts' Failure to Apply State LAW}

Federalism's quiet victory in Perry has gone unnoticed. In the academy, scholars have not written about it. In courtrooms, litigants have not raised it. A survey of recent federal court decisions shows that the Supreme Court's endorsement of state law in arbitration is a revolution unrecognized. Federal courts have continued to disregard

\footnotetext{
agreement is established under state law principles involving formation, revocation, and enforcement of contracts generally).

59. See supra note 11 .

60. See Merrell Dow Pharm., Inc. v. Thompson, 478 U.S. 804, 808 (1986) (restricting federal court jurisdiction in lawsuits in which federal and state law questions are mixed).

61. See infra notes 104-06 and accompanying text.

62. See infra Part IV.B.

63. 304 U.S. 64, 78 (1938).

64. See infra Part IV.A.

65. See infra Part V.
} 
state law when deciding the threshold question of whether parties agreed to submit their disputes to arbitration. ${ }^{66}$ This Part describes a typical fact pattern from construction law for which Perry should provide the rule of decision. It also examines a recent federal appeals court decision that exemplifies federal courts' neglect of state law.

\section{A. A Typical Fact Pattern: Binding a Contract Nonsignatory to an Arbitration Agreement}

The threshold question of whether a party agreed to be bound by a contract's arbitration clause often arises in the context of the nonsignatory. In the typical case, one of two parties who signed an agreement containing an arbitration clause seeks to compel a third party who did not sign the agreement to participate in arbitration. ${ }^{68} \mathrm{It}$ is well settled that nonsignatories to an arbitration agreement may be bound according to ordinary principles of (1) incorporation by reference, ${ }^{69}(2)$ assumption, ${ }^{70}(3)$ agency, ${ }^{71}(4)$ veil-piercing, ${ }^{72}$ and (5) estoppel. $^{73}$ Federal courts have erred by failing to apply state law to the

66. E.g., Keystone Shipping Co. v. New England Power Co., 109 F.3d 46 (1st Cir. 1997) (holding, solely on the basis of federal case law, that the plaintiff was contractually bound to arbitration); Commercial Union Ins. Co. v. Gilbane Bldg. Co., 992 F.2d 386, 388 (1st Cir. 1993) (same); United States Fid. \& Guar. Co. v. West Point Constr. Co., 837 F.2d 1507, 1507-08 (11th Cir. 1988) (same); O’Connor \& Co., Inc. v. Ins. Co. of N. Am., 697 F. Supp. 563, 564-67 (D. Mass. 1988) (same); Cianbro Corp. y Empresa Nacional de Ingenieria v. Technologia, S.A., 697 F. Supp. 15, 17-20 (D. Me. 1988) (same).

67. Another interesting phenomenon (beyond the scope of this Note) is the tendency of state courts to make the same mistake the federal courts have made. When faced with an allegation that the Arbitration Act applies, state courts may disregard their own contract law precedents in favor of poorly reasoned federal precedent. Because the Supreme Court has held that the Arbitration Act is applicable in state as well as federal courts, state courts incorrectly may assume that "federal contract law" is binding on them.

68. In one variation on the typical case, the nonsignatory may seek to compel a signatory to arbitrate. In that case, the inquiry is the same: Did the signatory and the nonsignatory agree to submit their dispute to arbitration? Are the signatory and nonsignatory in privity?

69. E.g., Keystone Shipping, 109 F.3d at 51.

70. E.g., Am. Bureau of Shipping v. Tencara Shipyard S.P.A., 170 F.3d 349, 352 (2d Cir. 1999).

71. E.g., Arnold v. Arnold Corp., 920 F.2d 1269, 1281 (6th Cir. 1990).

72. E.g., J.J. Ryan \& Sons, Inc. v. Rhone Poulenc Textile, S.A., 863 F.2d 315, 320-21 (4th Cir. 1988) ("When the charges against a parent company and its subsidiary are based on the same facts and are inherently inseperable, a court may refer claims against the parent to arbitration even though the parent is not formally a party to the arbitration agreement.").

73. E.g., Smith/Enron Cogeneration Ltd. P'ship v. Smith Cogeneration Int'l, Inc., 198 F.3d 88, 97 (2d Cir. 1999). 
threshold question in each of these five contexts. ${ }^{74}$ The remainder of this Note discusses this error in the context of the incorporation-byreference cases (even though its analysis is equally valid in the other four contexts). The incorporation-by-reference cases provide a good example of this error, because they involve a relatively simple fact pattern familiar to practitioners.

Disputes about the incorporation by reference of arbitration clauses most frequently arise in the context of construction agreements. ${ }^{75}$ There are two reasons this is so. First, more than almost any other industry, the construction industry has made use of arbitration as a means of settling disputes. ${ }^{76}$ Second, large construction projects require multiple layers of contractual relationships among owners, developers, contractors, subcontractors, sub-subcontractors, lessors, sureties, and others. ${ }^{77}$ Although these parties do not intend to be in direct contractual privity with every other party, they often are joined by a complex web of incorporations by reference. ${ }^{78}$

For an ordinary construction project, a developer and a general contractor sign a construction agreement containing an arbitration clause. $^{79}$ The general contractor then enters into contractual relationships with other parties, such as subcontractors and sureties. ${ }^{80}$ In most cases, the subcontract or performance bond does not contain an arbitration clause but does contain a provision incorporating by reference the underlying construction agreement. ${ }^{81}$ Oftentimes, the performance bond or subcontract contains language that suggests litigation is the agreed-upon method for resolving disputes ${ }^{82}-$ a feature that automatically puts the secondary agreement at odds with the primary. The question presented by these cases is whether the incorporation

74. E.g., Keystone Shipping, 109 F.3d at 51 (incorporation by reference); Tencara Shipyard, 170 F.3d at 353 (assumption); Arnold, 920 F.2d at 1281 (agency); J.J. Ryan \& Sons, 863 F.2d at 320-21 (veil-piercing); Sunkist Soft Drinks, Inc. v. Sunkist Growers, Inc., 10 F.3d 753, 757-58 (11th Cir. 1993) (estoppel).

75. J. Michael Franks \& John W. Heacock, Arbitration and the Contract Surety: Inclusion and Preclusion, 32 TORT \& INS. L.J. 977, 980 (1997).

76. Id.

77. Id.

78. Id.

79. Id. at $980 \mathrm{n} .18$.

80. Id. at 980 .

81. Id. at 981 .

82. E.g., Am. Inst. of Architects, Document A312: Performance Bond and Payment Bond 2 (1984) ("Any proceeding, legal or equitable, under this Bond may be instituted in any court of competent jurisdiction in the location in which the work or part of the work is located ...."). 
by reference binds a surety ${ }^{83}$ (or guarantor) or subcontractor to submit to arbitration or whether the reference to the underlying contract merely serves to define the scope, quality, character, and manner of the nonsignatory's performance. ${ }^{84}$

This question has become dismayingly common in construction disputes because the standard form contracts drafted by the American Institute of Architects and used by most contractors ${ }^{85}$ follow this pattern. ${ }^{86}$ Because these contracts are ambiguous when construed together, litigation over which parties consented to an arbitration clause has become a standard part of many construction disputes.

\section{B. United States Fidelity \& Guaranty Co. v. West Point Construction Co., Inc.}

The Eleventh Circuit's 1988 decision in United States Fidelity \& Guaranty Co. v. West Point Construction $\mathrm{Co}^{87}$ is notable for two reasons. First, although the case was decided almost a year after Perry, the Eleventh Circuit failed to observe controlling state contract law. Second, United States Fidelity has become the leading case on the question of whether a surety or subcontractor is bound to arbitrate disputes arising out of an underlying agreement that is incorporated by reference in a performance bond or subcontract. Courts have per-

83. In a contract of surety or guaranty, the surety or guarantor have promised to answer for the debt or default of a third person. 38 AM. JUR. 2D Guaranty $\S 11$ (1999). Both are accessory contracts. $I d$. In fact, "[s]ome authorities hold that a contract of guaranty is not distinguishable from a contract of suretyship, and the distinction has sometimes been repealed by statute." Id.

84. In other words, A and B sign an agreement containing an arbitration clause. B and C then sign a collateral agreement (a subcontract or performance bond) that incorporates the main agreement by reference. Disputes arise, and A seeks to compel $\mathrm{C}$ to submit to arbitration. $\mathrm{C}$ resists arbitration on the ground that no agreement to arbitrate exists between $\mathrm{C}$ and $\mathrm{A}$.

85. Franks \& Heacock, supra note 74, at 980 n.18 ("The standard form documents prepared by the American Institute of Architects . . are heavily relied upon and have virtually become scripture in the construction industry.").

86. See Am. Inst. of Architects, Document A20 1-1997: General Conditions of the Contract for Construction $\S 4.6 .2$ (1997) [hereinafter Am. Inst. of Architects, General Conditions] (the American Institute of Architects standard form construction agreement between an owner and contractor) (providing that disputes "arising out of or related to the Contract" shall be resolved in accordance with the Construction Industry Arbitration Rules of the American Arbitration Association); Am. Inst. of Architects, Document A311/CM: Performance Bond and Labor and Material Payment Bond 1 (1980) [hereinafter Am. Inst. of Architects, Performance Bond] (incorporating by reference the construction agreement); see also Am. Inst. of Architects, supra note 82 , at 2 (incorporating by reference the construction agreement).

87. 837 F.2d 1507 (11th Cir. 1988). 
petuated United States Fidelity's error by following its holding more than twenty times. ${ }^{88}$

In United States Fidelity, West Point Construction Company was a general contractor building the Lee County Justice Center in Alabama. ${ }^{89}$ West Point hired a subcontractor to paint. ${ }^{90}$ When the painter defaulted on its contract with West Point, West Point sought to institute arbitration proceedings against United States Fidelity, the painter's surety. ${ }^{91}$ United States Fidelity opposed arbitration. ${ }^{92}$ The subcontract between West Point and the painter included an arbitration clause, but the performance bond issued by United States Fidelity did not. ${ }^{93}$ The performance bond did, however, incorporate the subcontract by reference. ${ }^{94}$ Although United States Fidelity never signed any document containing an arbitration clause, the Eleventh Circuit held, as a matter of federal law, that the incorporation of a subcontract by reference into a performance bond expresses an intention of the parties, including the surety, to arbitrate disputes. ${ }^{95}$

The Eleventh Circuit's decision cannot be reconciled with Perry. The court did not consider Alabama or any other state's contract law, even though the question of whether the parties intended to be bound by the arbitration clause unquestionably concerned the "validity, revocability, and enforceability of contracts generally", and should have been governed by state contract law. The Alabama contract principles that should have governed the transaction-principles dealing with the parties' intentions and whether there was a "meeting of the minds"- do not take their "meaning precisely from the fact that a contract to arbitrate is at issue," nor do they place "arbitration agreements in a class apart from 'any contract,' and singularly limit[]

88. United States Fidelity has been followed at least twenty-three times. See, e.g., Rashid v. United States Fid. \& Guar. Co., CIV.A.No. 2:9 1-0141, 1992 WL 565341, at *7 (S.D. W. Va. Sept. 28, 1992); Transamerica Premier Ins. Co. v. Collins \& Co., Gen. Contr., Inc., 735 F. Supp. 1050, 1051 (N.D. Ga. 1990); Cianbro Corp. v. Empresa Nacional de Ingenieria y Technologia, S.A., 697 F. Supp. 15, 18 (D. Me. 1988).

89. 837 F.2d at 1507.

90. Id.

91. Id.

92. $I d$.

93. Id. at 1508 .

94. Id.

95. Id.

96. 428 U.S. at 493 n.9; see supra note 52 (indicating the opinions of the individual Justices).

97. Id. 
their validity." ${ }^{98}$ So they are not preempted by the Federal Arbitration Act. ${ }^{99}$ Nonetheless, the Eleventh Circuit ignored state law: it cited two federal court decisions as precedent, distinguished five federal court decisions as not relevant, and cited no state court decisions. ${ }^{100}$

What prompted the Eleventh Circuit to neglect the choice-of-law analysis prescribed by Perry? As an initial matter, the surety's lawyers probably did not think to raise the issue. Because of the Supreme Court's nationalization of arbitration law, lawyers tend to assume that state law no longer has any role in disputes over arbitration. The federalism aspect of Perry is subtle, and, for reasons explained in Part III, it has remained below the radar of most practitioners. Second, the Eleventh Circuit followed federal court decisions rendered before Perry that were exactly on point. The Eleventh Circuit noted that its holding was "consistent with" Exchange Mutual Insurance Co. v. Haskell Co., ${ }^{101}$ "in which the Sixth Circuit held under almost identical circumstances that the surety was bound to arbitrate by virtue of the incorporation into the performance bond of a subcontract which itself incorporated an arbitration clause." 102 Although the litigants probably did not notify the court of the fact, the Sixth Circuit decided Exchange Mutual three years before the Supreme Court decided Perry. Perry superceded Exchange Mutual. Exchange Mutual therefore was not a reliable authority for the proposition that the question of the parties' intent is to be decided as a matter of federal law.

The Eleventh Circuit in United States Fidelity attempted to buttress its decision by referring to "the strong policy favoring arbitration expressed by Congress in the Federal Arbitration Act." ${ }^{, 103}$ Courts typically invoke this "liberal federal policy favoring arbitration"-which the Supreme Court first announced in Moses H. Cone Memorial Hospital v. Mercury Construction Corp. ${ }^{104}$ - to put a thumb on the scale in

98. Doctor's Assocs., Inc. v. Casarotto, 517 U.S. 681, 688 (1996).

99. See Cione v. Foresters Equity Servs., Inc., 68 Cal. Rptr. 2d 167, 171 (Cal. Ct. App. 1997) (holding that even if one of the parties contends that the Arbitration Act applies to their agreement to arbitrate, federal law does not apply until the existence of an enforceable arbitration agreement is established under state law principles involving formation, revocation, and enforcement of contracts generally).

100. United States Fid., 837 F.2d at 1508.

101. 742 F.2d 274 (6th Cir. 1984).

102. United States Fid., 837 F.2d at 1508.

103. Id.

104. 460 U.S. 1, 24 (1983). 
favor of the party seeking arbitration..$^{105}$ But after Perry, this use of the federal government's pro-arbitration presumption is error. The federal presumption should not be permitted to taint the threshold question of whether an arbitration agreement exists, a pure question of state law. Under the Supreme Court's jurisprudence, "“any doubts concerning the scope of arbitrable issues should be resolved in favor of arbitration, whether the problem at hand is the construction of the contract language itself or an allegation of waiver, delay or a like defense to arbitrability." "106 The question of whether a valid arbitration agreement exists is not a question about the scope of arbitrable issues. The scope of arbitrable issues is not implicated until after a court has decided an agreement exists.

In United States Fidelity, the Eleventh Circuit should not have invoked the federal presumption in deciding whether the contractor and the surety intended to submit their disputes to arbitration. Once the court decided an arbitration agreement existed under state law, however, it would have been proper to invoke the presumption in finding (for example) that the arbitration agreement included within its scope disputes over the timeliness of the painter's performance.

The Eleventh Circuit's approach has been influential, notwithstanding the fact that it conflicts with the Supreme Court's instruction in Perry. Federal courts have followed United States Fidelity in droves, deciding as a matter of federal law that a valid arbitration agreement exists when a subcontract or performance bond incorporates by reference a contract containing an arbitration clause. In recent years, the Seventh Circuit in Gingiss International, Inc. v. Bormet ${ }^{107}$ and Grundstad v. Ritt, ${ }^{108}$ the First Circuit in Commercial Union Insurance Co. v.

105. See, e.g., Bercovitch v. Baldwin Sch., Inc., 133 F.3d 141, 147 (1st Cir. 1998) ("The issue of arbitrability must be analyzed in light of the strong public policy favoring arbitration ....").

106. Mitsubishi Motors Corp. v. Soler Chrysler-Plymouth, Inc., 473 U.S. 614, 626 (1985) (quoting Moses H. Cone, 460 U.S. at 24-25) (emphasis added).

107. 58 F.3d 328 (7th Cir. 1995). In Gingiss, the Seventh Circuit ignored state law in deciding that guarantors were bound by the arbitration clause in a franchise agreement they had not signed, because the guaranty incorporated by reference the franchise agreement. Id. at 331. The court cited a 1985 Fourth Circuit decision, Maxum Foundations, Inc. v. Salus Corp., 779 F.2d 974, 978 (4th Cir. 1985), and a 1984 Sixth Circuit decision, Exchange Mutual Insurance Co. v. Haskell Co., 742 F.2d 274, 276 (6th Cir. 1984), for the proposition that " [u]nder federal law, a subcontract with a guarantor or surety may incorporate a duty to arbitrate by reference to an arbitration clause in a general contract." Gingiss, 58 F.3d at 331-32 (emphasis added). The shareholders therefore were obligated to arbitrate. Id.

108. 106 F.3d 201 (7th Cir. 1997). The Grundstad court disregarded the Supreme Court's instruction that federal courts must as a threshold matter apply state law to determine whether the parties agreed to arbitrate. Id. at 204-05. The court did not cite a single state court decision. 
Gilbane Building Co. ${ }^{109}$ a federal district court in New Jersey in Hoffman v. Fidelity \& Deposit Co. ${ }^{110}$ a federal district court in Maine in Cianbro Corp. v. Empresa Nacional de Ingenieria y Technologia, S.A. ${ }^{111}$ and a federal district court in Massachusetts in Thomas O'Connor \& Co. v. Insurance Co. of North America ${ }^{112}$ all failed to apply state law at the threshold.

Even more courts have made the same error in contexts having nothing to do with incorporation by reference. For example, the Ninth Circuit has held that federal law, not state law, governs the question of whether an arbitration agreement is an adhesion contract $^{113}$ and that the Arbitration Act creates a single, unified body of federal law that governs all defenses against the validity of an arbitration agreement. ${ }^{14}$ Neither of these decisions can be reconciled with Perry or the Supreme Court decisions that followed it.

Instead, the court followed a decision from another federal circuit (a decision that also failed to apply state law). $I d$.

109. 992 F.2d 386 (1st Cir. 1993). The Gilbane court decided that a performance bond (with no arbitration clause) that, in turn, incorporated by reference a subcontract (with no arbitration clause) that incorporated by reference a prime contract (containing an arbitration clause) created a "chain of incorporation" sufficient to bind the general contractor to arbitrate its disputes with the surety. $I d$. at 388-89. In reaching that result, the First Circuit ignored applicable state law (from Massachusetts), cited the "strong federal policy favoring arbitration agreements," and followed an old Sixth Circuit decision. See id. (citing Exch. Mut., 742 F.2d at 275-76).

110. 734 F. Supp. 192 (D.N.J. 1990). The Hoffman court applied "federal substantive law" to the threshold inquiry to find that a surety was bound to an arbitration agreement between a contractor and a real estate owner. Id. at 194. The court noted that "federal policy favors arbitration and dictates liberal construction of arbitration clauses." Id. at 195. It observed that "the Eleventh, Sixth, Fifth, Second, and First Circuits, and several district courts, ha[d] required sureties to arbitrate issues relating to a performance bond where the performance bond incorporate[d] by reference a contract containing an arbitration clause." Id. at 194. The court ignored the relevant state law from New Jersey, even though New Jersey courts had considered the exact issue presented. See infra notes 190-91 and accompanying text.

111. 697 F. Supp. 15 (D. Me. 1988). In ordering a surety to arbitrate based on an incorporation by reference, the Cianbro court ignored state law, cited a "healthy regard for the federal policy [favoring] arbitration," and followed a series of federal decisions from other circuits, none more recent than 1984, except for the Eleventh Circuit's suspicious 1988 decision in United States Fidelity. Id. at 17-19 (citing United States Fid. \& Guar. Co. v. West Point Constr. Co., 837 F.2d 1507 (11th Cir. 1988)). For a criticism of United States Fidelity, see supra notes 87-106 and accompanying text.

112. 697 F. Supp. 563 (D. Mass. 1988). In holding that a subcontractor was bound to the arbitration agreement in an underlying agreement incorporated by reference into the subcontract, a federal district court in Massachusetts made no mention of state law and instead cited a 1975 First Circuit decision and a 1984 Sixth Circuit decision. Id. at 565 (citing Exch. Mut., 742 F.2d at 274, and J \& S Constr. Co. v. Travelers Indem. Co., 520 F.2d 809 (1st Cir. 1975)).

113. Mago v. Shearson Lehman Hutton, Inc., 956 F.2d 932, 934 (9th Cir. 1992).

114. Cohen v. Wedbush, Noble, Cooke, Inc., 841 F.2d 282, 285 (9th Cir. 1988); see also Neal v. Hardee's Food Sys., Inc., 918 F.2d 34, 37 n.5 (5th Cir. 1990) (holding that federal law gov- 


\section{EXPLAINING THE FAILURE TO OBSERVE STATE LAW}

There are two main reasons federal courts continue to apply federal contract law to the threshold question of whether the parties agreed to arbitrate. First, the law in this area is exceptionally difficult and confusing, Perry v. Thomas notwithstanding. Second, there are some good (though ultimately unpersuasive) policy arguments for following cases like United States Fidelity.

\section{A. The Supreme Court's Jungle of Jurisprudence}

The Supreme Court's Federal Arbitration Act jurisprudence is a challenge to understand and apply, particularly with respect to choice-of-law questions. For that reason, lawyers typically assume (and tell judges) that federal law governs the threshold question. The Supreme Court frequently states that the Arbitration Act creates a "body of federal substantive law" establishing and regulating the duty to honor an agreement to arbitrate. ${ }^{115}$ While this is undoubtedly true, some lower courts have interpreted this statement broadly to mean that the Act authorizes courts to fashion federal common law to govern the threshold question of whether the parties entered into an agreement to arbitrate. ${ }^{116}$ These courts have purported to follow Mitsubishi Motors Corp. v. Soler Chrysler-Plymouth, Inc. ${ }^{117}$ a $1985 \mathrm{Su}-$ preme Court decision that appears to endorse the application of federal law to the threshold inquiry. The Court in Mitsubishi stated:

[T] he first task of a court asked to compel arbitration of a dispute is to determine whether the parties agreed to arbitrate that dispute.

The court is to make this determination by applying the "federal

erned the question of whether separate agreements should be construed together to determine if an arbitration agreement had been formed); Degaetano v. Smith Barney, Inc., No. 95 CIV. 1613 (DLC), 1996 U.S. Dist. LEXIS 1140, at *9-*10 (S.D.N.Y. Feb. 5, 1996) (holding that courts must apply federal substantive law to determine arbitrability); In re Milliken \& Co., No. 92 CIV. 0773 (CSH), 1992 U.S. Dist. LEXIS 11195, at *19 (S.D.N.Y. July 30, 1992) (“[T]he Second Circuit has clearly stated that whether parties are bound by an arbitration clause under the [Arbitration Act] is determined by federal law, not state law.”).

115. Southland Corp. v. Keating, 465 U.S. 1, 12 (1984); Moses H. Cone Mem'l Hosp. v. Mercury Constr. Corp., 460 U.S. 1, 25 n.32 (1983).

116. Neal, 918 F.2d at 37 n.5; Genesco, Inc. v. T. Kakiuchi \& Co., 815 F.2d 840, 845 (2d Cir. 1987) (binding a party to an arbitration agreement printed on the back of a sales confirmation form).

117. 473 U.S. 614 (1985). 
substantive law of arbitrability, applicable to any arbitration agreement within the coverage of the Act." 118

The Court's statement must be read within the context of Mitsubishi's facts. In Mitsubishi, neither the formation nor the existence of the arbitration agreement was at issue. In fact, the Mitsubishi Court assumed the existence of such an agreement. ${ }^{119}$ The only issue was whether a court should enforce an agreement to resolve a certain type of claim-antitrust claims-by arbitration. ${ }^{120}$ The issue concerned not the existence of the agreement, but the scope of the agreement. The language of Mitsubishi ("the first task of a court asked to compel arbitration of a dispute is to determine whether the parties agreed to arbitrate that dispute") ${ }^{121}$ is relevant not to the threshold inquiry, but to the question of whether a particular dispute falls within the ambit of an arbitration agreement. Nonetheless, lawyers and courts can be forgiven for failing to draw so fine a distinction.

Lower courts also have been misled by the generous, proarbitration rhetoric that has accompanied Supreme Court decisions dealing with the scope of arbitrable disputes. For example, the Supreme Court noted in AT\&T Technologies, Inc. v. Communications Workers of America: ${ }^{122}$

[W]here the contract contains an arbitration clause, there is a presumption of arbitrability in the sense that "[a]n order to arbitrate the particular grievance should not be denied unless it may be said with positive assurance that the arbitration clause is not susceptible of an interpretation that covers the asserted dispute. Doubts should be resolved in favor of coverage."

The language in AT\&T Technologies, Inc., like the language in Mitsubishi, refers to the scope of the agreement, not to the threshold question of its existence.

In Volt Information Sciences, Inc. v. Board of Trustees of Leland Stanford Junior University, ${ }^{124}$ the Supreme Court stated that "in ap-

\footnotetext{
118. Id. at 626 (quoting Moses H. Cone, 460 U.S. at 24).

119. Id. at 628 ("We now turn to consider whether Soler's antitrust claims are nonarbitrable even though it has agreed to arbitrate them.").

120. Id. at 624 .

121. Id. at 626 (emphasis added).

122. 475 U.S. 643 (1986).

123. Id. at 650 (assuming the existence of a valid agreement to arbitrate) (quoting United Steelworkers v. Warrior \& Gulf Navigation Co., 363 U.S. 574, 582-83 (1960)) (emphasis added). 124. 489 U.S. 468 (1989).
} 
plying general state-law principles of contract interpretation to the interpretation of an arbitration agreement within the scope of the Act, due regard must be given to the federal policy favoring arbitration, and ambiguities as to the scope of the arbitration clause itself resolved in favor of arbitration." ${ }^{25}$ Despite its appearance, this language does not support the proposition that the federal policy favoring arbitration is relevant to the threshold inquiry. Neither the existence nor the formation of the arbitration agreement was disputed in Volt. The Court assumed at the outset that such an agreement existed and that the agreement was "within the scope of the Act."126 The only reason that state law was at issue in Volt was because the parties specifically incorporated California law into their arbitration agreement. ${ }^{127}$ The Court therefore applied California law (with due regard to the federal policy) to the interpretation of the contract, not to the threshold inquiry of whether it existed. Again, lower courts can be forgiven for overreading the federal policy in favor of arbitration.

None of the Supreme Court's pronouncements on the Arbitration Act appeared to endorse any role for state law before the 1987 decision in Perry v. Thomas. ${ }^{128}$ Perry states clearly that "state law, whether of legislative or judicial origin, is applicable if that law arose to govern issues concerning the validity, revocability, and enforceability of contracts generally." ${ }^{129}$ Nonetheless, this language is not very prominent in the opinion. The language appears in a footnote, and it often is overshadowed by the Court's robust explanation of what state law does not apply: state principles hostile to arbitration. ${ }^{130}$ Only a handful of lower courts have recognized that Perry instructed them to apply state law to the threshold inquiry. ${ }^{131}$ It was not until First $O p$ -

\footnotetext{
125. Id. at $475-76$ (citations omitted).

126. Id. at 475 .

127. Id. at 470 .

128. 482 U.S. 483 (1987).

129. Id. at 493 n.9.

130. Id.

131. E.g., Progressive Cas. Ins. Co. v. C.A. Reaseguradora Nacional de Venez., 991 F.2d 42, 46 (2d Cir. 1993) (noting that although "the Arbitration Act preempts state law which treats arbitration agreements differently from any other contracts, it also "preserves general principles of state contract law as rules of decision on whether the parties have entered into an agreement to arbitrate"') (quoting Cook Chocolate Co. v. Salomon, Inc., 684 F. Supp. 1177, 1182 (S.D.N.Y. 1988)); Cione v. Foresters Equity Servs., Inc., 68 Cal. Rptr. 2d 167, 171 (Cal. Ct. App. 1997) (holding that, even if one of the parties contends that the Arbitration Act applies to their agreement to arbitrate, the Act does not apply until the existence of an enforceable arbitration agreement is established under state law principles involving formation, revocation, and enforcement of contracts generally).
} 
tions of Chicago, Inc. v. Kaplan ${ }^{132}$ in 1995 that the Supreme Court remedied this shortcoming. In First Options, the Court clearly and prominently stated: "When deciding whether the parties agreed to arbitrate a certain matter (including arbitrability), courts generally ... should apply ordinary state-law principles that govern the formation of contracts." $" 133$

In light of this minefield of Supreme Court precedent, it is little wonder that lower courts mistakenly fashion federal common law to govern the threshold inquiry of whether an arbitration agreement existed between the parties.

The lower courts' error has perpetuated itself. When faced with the jungle of jurisprudence the Supreme Court has established during the last twenty years, courts seeking clarity have found it in precedents like United States Fidelity. ${ }^{134}$ Lower courts have latched onto the clear-but (it now seems) clearly wrong-rules laid down in United States Fidelity and its progeny. ${ }^{135}$ Bad law has multiplied.

\section{B. Policy Arguments in Favor of a Federal Rule of Decision}

Another likely explanation for lower courts' failure to apply state contract principles to the threshold inquiry is the fact that per se federal contract rules of the kind laid down in United States Fidelity appear attractive from a policy standpoint, at least at first glance. The existence of a single, nationwide, federal rule of decision could simplify both the ex ante planning of contractual relations and the ex post resolution of disputes. Local rules, on the other hand, require extensive legal research and factfinding, increasing the costs, unpredictability, and delays associated with adjudication. The purpose of the Federal Arbitration Act is to minimize such problems.

Some judges may be concerned that the application of state law will treat the threshold question as fact-bound and, therefore, appro-

\footnotetext{
132. 514 U.S. 938 (1995).

133. Id. at 944 . The Court reserved one qualification to the general rule that state law governs the threshold inquiry. When courts decide whether a party has agreed that arbitrators should decide arbitrability, state law does not apply to that question. Rather, courts should follow the federal rule that parties have not agreed to arbitrate arbitrability unless there is "clear and unmistakable evidence" that they did so. Id. (quoting AT\&T Techs., Inc. v. Communications Workers of Am., 475 U.S. 643, 649 (1986)).

134. United States Fid. \& Guar. Co. v. West Point Constr. Co., 837 F.2d 1507 (11th Cir. 1988).

135. United States Fidelity has been cited more than twenty times. See supra note 88 and accompanying text.
} 
priate for decision by a jury. ${ }^{136}$ Empanelling a jury to decide the threshold issue of whether the parties agreed to forego judicial decisionmaking seems contrary to the Act's core purpose of allowing parties to agree to select a less costly alternative to litigation, and then to proceed in that alternative forum without delay imposed in the courts. ${ }^{137}$ Also, juries would be required to consider potentially unreliable parol evidence as to the parties' intentions. Moreover, turning the threshold question over to jurors could cast doubt on the enforceability of arbitration agreements, thereby discouraging trade and squandering scarce judicial resources. ${ }^{138}$ And federal judges who complain about swollen court dockets may find that discouraging jury trials lightens their load. ${ }^{139}$

Courts that followed United States Fidelity and applied its federal rule of decision may have been concerned that applying state contract principles would cause waste for other reasons, in addition to the waste associated with empanelling a jury. For example, if courts did not follow the United States Fidelity rule-that a performance bond's reference to the underlying agreement binds the surety to its arbitration clause-plaintiffs might be forced to proceed against the principal and the surety in separate forums (the principal in the arbitration forum, the surety in court). Factfinding would occur simultaneously in both forums, causing redundancy. This result might appear especially obnoxious because in some jurisdictions the liability of the surety and the principal are coextensive. ${ }^{140}$ Because the surety stands in the shoes

136. Carrington \& Haagen, supra note 19, at 397. For an example of a case that should have treated the threshold determination as fact-bound, see infra note 185 and accompanying text.

137. See Scherk v. Alberto-Culver Co., 417 U.S. 506, 510-11 (1974) ("The United States Arbitration Act... was designed to allow parties to avoid 'the costliness and delays of litigation' ....") (citation omitted); Prima Paint Corp. v. Flood \& Conklin Mfg. Co., 388 U.S. 395, 404 (1967) (referring to "the unmistakably clear congressional purpose that the arbitration procedure, when selected by the parties to a contract, be speedy and not subject to delay and obstruction in the courts").

138. Carrington \& Haagen, supra note 19, at 332 (noting that encouraging trade and preserving judicial resources are among the purported benefits of arbitration).

139. See Sec. Indus. Ass'n v. Connolly, 883 F.2d 1114, 1116 (1st Cir. 1989) (noting that the Act was "therapy for the ailment of the crowded docket"). But see Casarotto v. Lombardi, 886 P.2d 931, 940 (Mont. 1994) (Trieweiler, J., specially concurring) (noting that the First Circuit's opinion in Securities Industry Ass' $n$ illustrated "an all too frequent preoccupation on the part of federal judges with their own case load and a total lack of consideration for the rights of individuals"), vacated and remanded by 515 U.S. 1129 (1995), reaff'd and reinstated by 901 P.2d 596 (Mont. 1995), rev'd 517 U.S. 681 (1996).

140. E.g., Am. Home Assurance Co. v. Larkin Gen. Hosp., Ltd., 593 So. 2d 195, 198 (Fla. 1992). 
of the principal, it should be subject to the same rights and remedies as the principal-and in the same forum.

Application of state law also might encourage parties to attempt to evade arbitration, the agreed-upon procedure for resolving disputes, by introducing the identical controversy in a judicial forum. Congress enacted the Arbitration Act to make dispute resolution cheaper and faster; such piecemeal adjudication threatens to make it more costly and time-consuming. Moreover, piecemeal adjudication risks creating inconsistent judgments. For example, a developer could win a court judgment against the surety, but lose in the arbitration proceeding against the principal contractor. Inconsistent results are minimized if the surety is compelled to participate in arbitration alongside the principal.

Although these arguments are compelling, they must be taken with a grain of salt. It is true that the Arbitration Act was intended to lower the costs of adjudication, ${ }^{141}$ but it is not true that the Act was intended to abridge the right to jury trial. In fact, where a party denies having agreed to arbitration, the Act explicitly affirms the right to jury trial, except in admiralty cases: ${ }^{142}$

If the making of the arbitration agreement or the failure, neglect, or refusal to perform the same be in issue, the court shall proceed summarily to the trial thereof. If no jury trial be demanded by the party alleged to be in default, or if the matter in dispute is within admiralty jurisdiction, the court shall hear and determine such issue. $^{143}$

The Arbitration Act is not offended by a jury or judge weighing the evidence to determine whether the parties intended to forego a judicial forum for the resolution of disputes. Therefore, it is inappropriate for a court to adopt on policy grounds a federal contract rule in lieu of conducting a fact-intensive inquiry into the parties' intentions.

Moreover, the Supreme Court on two occasions has downplayed concerns about piecemeal adjudication, while underscoring the importance of the parties' intentions. In Moses H. Cone Memorial Hospital v. Mercury Construction Corp. ${ }^{144}$ the Court held that a hospital's claim against a contractor was subject to arbitration, but the hospital's

141. Scherk, 417 U.S. at 510-11.

142. Carrington \& Haagen, supra note 19, at 349.

143. 9 U.S.C. $\$ 4$ (1994).

144. 460 U.S. 1 (1983). 
claim for indemnity against an architect was not subject to arbitration, since there was no arbitration agreement between the hospital and the architect. ${ }^{145}$ The Court noted that "the relevant federal law requires piecemeal resolution when necessary to give effect to an arbitration agreement." 146 The Court reiterated that holding in Dean Witter Reynolds, Inc. v. Byrd. ${ }^{147}$ The first principle of arbitration is that arbitration is "'a matter of contract and a party cannot be required to submit to arbitration any dispute which he has not agreed so to submit." ${ }^{148}$ While efficiency concerns are important, they do not outweigh a party's right to the remedy for which it bargained, whether that remedy is arbitration or litigation.

Finally, separate adjudication for the surety and principal is not necessarily wasteful. Although a surety and principal's obligations are linked, they are not identical. In some states, an arbitration award rendered against a principal alone carries no evidentiary weight in a proceeding against a surety. ${ }^{149}$ And in most states, the surety possesses defenses under the bond that are not available to the principal, such as waiver, notice and demand, statutory or contractual limitations on actions, fraud, the "cardinal change rule," and overpayment. ${ }^{150}$ In their haste to compel arbitration, courts too frequently overlook these distinctions.

In sum, although some policy arguments favor a federal rule of decision, none of these arguments is important enough to outweigh the Federal Arbitration Act's overriding policy of protecting contracting parties' intentions. ${ }^{151}$

145. Id. at $19-20$.

146. Id. at 20 .

147. 470 U.S. 213, 217 (1985) ("[T]he Arbitration Act requires district courts to compel arbitration of pendent arbitrable claims when one of the parties files a motion to compel, even where the result would be the possibly inefficient maintenance of separate proceedings in different forums.").

148. AT\&T Techs., Inc. v. Communications Workers of Am., 475 U.S. 643, 648 (1986) (quoting United Steelworkers v. Warrior \& Gulf Navigation Co., 363 U.S. 574, 582 (1960)).

149. E.g., CAL. CIV. CODE $\S 2855$ (West 2001).

150. Franks \& Heacock, supra note 75, at 981 ("Courts have been willing to bind a surety to the obligations of its principal because they mistakenly view their interests as being identical.").

151. AT\&T Techs., 475 U.S. at 648 (holding that arbitration is "a matter of contract and a party cannot be required to submit to arbitration any dispute which he has not agreed so to submit"). 


\section{Why State Rules of Decision ARE BetTer}

Part III outlined reasons federal contract rules might be superior to state contract rules at governing the threshold inquiry. This Part contends that the arguments in favor of state contract law are more persuasive. The federalist approach prescribed by the Supreme Court in Perry is superior for at least two reasons. First, the application of state contract law is more likely to protect the parties' intentions. Second, the application of state contract law preserves an important sphere of state sovereignty.

\section{A. Application of State Contract Law Protects Parties' Intentions}

Arbitration is a matter of contract; a party cannot be required to submit a dispute to arbitration unless it so agreed. ${ }^{152}$ Contract law historically has been the domain of the states. ${ }^{153}$ All states have welldeveloped contract principles designed to protect contracting parties' intentions. Contracting parties typically bargain against a background of well-known contract principles. Unlike state law, federal law does not include a well-developed set of contract principles, especially since the Supreme Court rejected the notion of a "general common law" in Erie Railroad Co. v. Tompkins. ${ }^{154}$ To the extent that a "federal contract law" exists, it is an amorphous grab bag of principles redolent of the era of the notorious Swift v. Tyson. ${ }^{155}$ Such principles are not well calculated to protect contracting parties' intentions. It is difficult, if not impossible, for contracting parties to bargain against this uncertain background.

Because of the uncertain contours of "federal contract law," courts that neglect state contract law are apt to apply federal per se rules of the kind laid down by the Eleventh Circuit in decisions like United States Fidelity. ${ }^{156}$ This rote application of a formal federal rule

152. Id. (noting that arbitrators derive their authority to resolve disputes only because the parties have agreed in advance to submit such grievances to arbitration); United Steelworkers, 363 U.S. at 582.

153. Jones, supra note 3, at 663 (noting that contract law is typically the domain of states, that the existence of a federal common law of contract was rejected in Erie R.R. Co. v. Tompkins, 304 U.S. 64, 78 (1938), and that the "very concept of 'federal contract law' is . . amorphous").

154. 304 U.S. 64, 78 (1938).

155. 41 (16 Pet.) U.S. 1 (1842).

156. United States Fid. \& Guar. Co. v. West Point Constr. Co., 837 F.2d 1507 (11th Cir. 1988). 
is less likely to realize the parties' intentions than would a nuanced, fact-intensive examination based on state law. Consider, for example, the per se rule of United States Fidelity. The rule in that case would foreclose several potentially meritorious defenses available under state law. If, as a matter of federal law, a performance bond's reference to the underlying agreement binds the surety to its arbitration clause, a surety cannot defend itself by alleging that there was no meeting of the minds, that the contract language was ambiguous or inconsistent, that there was a mutual mistake, that the incorporation by reference was inadequate to incorporate all terms, that industry custom or usage dictate a certain construction, or that the agreement was unconscionable.

The danger that federal contract law will flout the parties' intentions is especially acute in the specific factual setting of United States Fidelity and its progeny. As a practical matter, sureties and subcontractors are not likely to have intended that their incorporation by reference of a prime contract bind them to its arbitration clause. Large construction projects require multiple layers of contractual relationships between owners, developers, contractors, subcontractors, sub-subcontractors, lessors, sureties, and others. ${ }^{157}$ Although these parties do not intend to be in direct contractual privity with every other party, they often are joined by a complex web of incorporations by reference. ${ }^{158} \mathrm{~A}$ court that fails to carefully apply state contract principles risks binding the parties to foreign contract terms they never intended to adopt:

The extensive tiering of contractual relationships on a construction project can lead to the proliferation of, and the consequently unintended adoption of, foreign contract terms. The owner is bound to a general contractor that is bound to a subcontractor that is bound to a sub-subcontractor. Although these many parties are not usually in direct privity with all of the others, their contracts frequently include language incorporating the terms of the other contracts by reference. Most of the standard form construction contracts contain such provisions. $^{159}$

157. Franks \& Heacock, supra note 75 , at 980.

158. Id.

159. Id. 
Performance bonds typically reference the prime contract. ${ }^{160}$ This reference exists so that the surety will know what obligation it is assuming. ${ }^{161}$ Such references exist to define the scope, quality, character, and manner of the surety's performance, and not necessarily the surety's rights and remedies. ${ }^{162}$ When a surety executes a performance bond, it probably intends to be bound to the obligations in the bond itself, and not to the obligations contained in the underlying agreement. ${ }^{163}$ The surety especially does not intend to be bound by the underlying agreement's arbitration clause. In fact, the standard form performance bond drafted by the American Institute of Architects (which has "virtually become scripture in the construction industry" $)^{164}$ specifically contemplates adjudication, not arbitration, as the remedy for disputes arising out of the bond. ${ }^{165}$

This conclusion that sureties do not intend to submit to arbitration when they execute a performance bond is bolstered by the fact that many sureties consider arbitration a bad forum for resolution of their disputes. ${ }^{166}$ The surety has no input in selecting the arbitrators or the ground rules for arbitration, since those terms are dictated by an agreement drafted by other parties and incorporated into the bond.

160. E.g., Am. Inst. of Architects, supra note 82, at 2 ("The Contractor and the Surety, jointly and severally, bind themselves, their heirs, executors, administrators, successors and assigns to the Owner for the performance of the Construction Contract, which is incorporated herein by reference.").

161. Franks \& Heacock, supra note 75 , at 981.

162. Id.

163. 11 Lee R. Russ \& Thomas F. Segalla, Couch on Insurance $§$ 163:34 (3d ed. 1995).

164. Franks \& Heacock, supra note 75 , at 980 n.18.

165. See Am. Inst. of Architects, supra note 82, at 2 ("Any proceeding, legal or equitable, under this Bond may be instituted in any court of competent jurisdiction in the location in which the work or part of the work is located ....").

166. Franks \& Heacock, supra note 75, at 977. Sureties are not the only ones questioning the quality of arbitration. See Edward Brunet, Questioning the Quality of Alternate Dispute Resolution, 62 TUL. L. REV. 1, 55 (1987) ("[D]ramatic expansion of ADR [alternative dispute resolution, including arbitration] could harm qualitative justice in a substantive way."); see also Sternlight, supra note 3, at 643:

[W]hile binding arbitration may well be preferable from the standpoint of certain segments of society-particularly large companies that draft the terms and court administrators and judges who can reduce their own workload-there is no reason to believe that society as a whole is better off with binding arbitration.

See generally Thomas J. Stipanowich, Rethinking American Arbitration, 63 IND. L.J. 425 (1988) (discussing empirical data about lawyers' and clients' perceptions of the advantages and disadvantages of arbitration). 
Arbitration also is an "unfriendly forum for assertion of the surety's legal defenses, leading to an understandable fear that a panel of lay arbitrators will view substantive legal defenses as 'mere technicalities." ${ }^{167}$ Arbitration typically is conducted by nonlawyers who might be "wholly unqualified to decide legal issues." ${ }^{, 168}$ Even if an arbitrator is qualified, he has no duty to resolve a dispute in compliance with the parties' legal rights. ${ }^{169}$ Because arbitrators are paid, they may feel market pressure to appear considerate even to parties that have abused the rights of others. ${ }^{170}$ Also, neither discovery nor meaningful appeal is available in arbitration. ${ }^{171}$

If courts continue to follow federal rules of decision like the one announced in United States Fidelity, instead of applying state contract principles to the threshold inquiry, they will subject parties (who never intended to forego their right to a day in court) to an unfriendly forum that inadequately protects their legal rights.

\section{B. Application of State Contract Law Protects State Sovereignty}

Perry v. Thomas teaches that the Federal Arbitration Act preserves a sphere of state sovereignty, even in cases where an arbitration agreement is alleged to exist. The Act leaves states ample room for lawmaking. State contract principles apply as long as they do not take their "meaning precisely from the fact that a contract to arbitrate is at issue." "172 So, for example, a state legislature could enact a law providing that clauses limiting procedural rights in standard form contracts are unconscionable and voidable by consumers. ${ }^{173}$ In such a

167. Franks \& Heacock, supra note 75, at 977.

168. Prima Paint Corp. v. Flood \& Conklin Mfg. Co., 388 U.S. 395, 407 (1967) (Black, J., dissenting).

169. Carrington \& Haagen, supra note 19, at 345.

170. Id. at 346 .

171. Id. at 347-48.

172. Perry v. Thomas, 482 U.S. 483, 493 n.9 (1987).

173. An effort is underway in some state legislatures to enact a model "Fair Bargain Act" that would have this effect. New Mexico recently enacted a version of this legislation. See Commercial Law-Enactment of Uniform Arbitration Act-Establishment of Standards for Proceedings, 2001 N.M. Laws 1935 (providing that a clause in a standard form contract or lease that modifies or limits procedural rights necessary or useful to a consumer, borrower, tenant, or employee in the enforcement of substantive rights against a party drafting the standard form contract or lease is unconscionable and is voidable by the consumer, borrower, tenant, or employee). Plans are underway in Arkansas and Connecticut to introduce similar bills. E-mail from Paul D. Carrington, Chadwick Professor of Law, Duke University School of Law, to Charles Davant IV (June 13, 2001) (on file with the Duke Law Journal). A version of the Fair Bargain Act recently was referred to the Illinois General Assembly House Rules Committee. 
state, many arbitration agreements would be rendered invalid because of defects in the bargaining process. But under Perry, the Federal Arbitration Act would not preempt the new law.

Preserving this sphere of state sovereignty is important for another reason. American federalism recognizes that the United States has a diverse political and social culture that varies by region. As Martin H. Redish and Elizabeth J. Cisar observed in a different context, "Because of vast differences from region to region (such as climate, ethnicity, and industry), it is unrealistic to expect all the citizens to possess the same goals and interests." might have different expectations about contracting, and state legislatures can recognize these differences better than the distant Congress. Regional differences also permit states to perform "their role as laboratories for experimentation to devise various solutions where the best solution is far from clear." 175 These benefits of federalism will remain unrealized, however, so long as courts continue to disregard state contract law at the threshold.

See Illinois Fair Bargain Act, House Bill 573, Illinois General Assembly (re-referred to House Rules Committee, Apr. 6, 2001), at http://www.legis.state.il.us/legisnet/legisnet92/hbgroups/hb/ 920HB0573LV.html (last visited Aug. 20, 2001) (on file with the Duke Law Journal).

New Mexico enacted its version of the Fair Bargain Act as an amendment to the state's Arbitration Act. See Commercial Law-Enactment of Uniform Arbitration Act-Establishment of Standards for Proceedings, 2001 N.M. 1935. Enacting these consumer protection provisions as a part of the Uniform Arbitration Act may have been tactically unwise. E-mail from Paul D. Carrington, supra. When a court is called upon in the future to say whether the Federal Arbitration Act preempts these consumer protection provisions, there is a danger the court will infer from the provisions' placement in the Uniform Arbitration Act that the state statute was intended to place arbitration agreements "apart from other kinds of contracts" and that the Federal Arbitration Act therefore preempts it under Doctor's Associates, Inc. v. Casarotto, 517 U.S. 681, 687 (1996).

174. Martin H. Redish \& Elizabeth J. Cisar, "If Angels Were to Govern": The Need for Pragmatic Formalism in Separation of Powers Theory, 41 DUKE L.J. 449, 469 (1991).

175. United States v. Lopez, 514 U.S. 549, 581 (1995); see also San Antonio Indep. Sch. Dist. v. Rodriguez, 411 U.S. 1, 49-50 (1973) (stating that as each locale tailors its programs to local needs, there is more opportunity for experimentation and innovation); New State Ice Co. v. Liebmann, 285 U.S. 262, 311 (1932) (Brandeis, J., dissenting) (stating that "[i]t is one of the happy incidents of the federal system that a single ... State may ... serve as a laboratory; and try novel social and economic experiments"). 


\section{DifFERENT COURTS, DifFERENT OUTCOMES: THE FEDERAL ARBITRATION ACT AND VERTICAL FORUM SHOPPING}

With bad precedents like United States Fidelity on the books, litigants are likely to face different legal rules depending on whether they proceed in state or federal court. This is so for two reasons. As a practical matter, federal judges are more likely to know and consider decisions rendered by federal courts. ${ }^{176}$ As a legal matter, federal judges feel bound by decisions rendered by federal courts (even suspicious decisions like United States Fidelity). ${ }^{177}$ The same is true for state judges and decisions rendered by state courts. ${ }^{178}$ If the federal system is likely to apply a different rule of law than the state system, vertical forum shopping is encouraged. Sureties and subcontractors will seek to avoid precedents like United States Fidelity (and therefore arbitration) by filing suit in state court. Developers and general contractors will seek to take advantage of such precedents by filing suit in federal court. If federal and state courts apply the same state contract principles to the threshold inquiry, as instructed by the Supreme Court, parties will be less likely to forum shop. Moreover, the parties will be less likely to be bound by a rule of law that is foreign to their dispute.

The case law provides ample evidence that federal courts applying federal law to the threshold inquiry reach results different from what they would have reached under state law. ${ }^{179}$ This is so because

176. Michael B. Mushlin, Unsafe Havens: The Case for Constitutional Protection of Foster Children from Abuse and Neglect, 23 HARV. C.R.-C.L. L. REV. 199, 258 (1988).

177. Burt Neuborne, The Myth of Parity, 90 HARV. L. REV. 1105, 1124-25 (1977) ("[F]ederal judges appear to recognize an affirmative obligation to carry out and even anticipate the direction of the Supreme Court. Many state judges, on the other hand, appear to acknowledge only an obligation not to disobey clearly established law.").

178. Mushlin, supra note 176, at 258 ("Most of the state judge's time is spent adjudicating claims that arise solely under a particular state's laws.").

179. At the outset, it must be conceded that in many cases a federal court will reach the proper state-law result, even though it fails to apply state law. That is because a court attempting to apply "federal contract law," or "generally accepted principles of contract law," may apply general contract principles identical to those of the relevant state. Moreover, a federal court that fails to apply state law might fortuitously follow a federal precedent whose holding is identical to state precedent. That was the situation in the First Circuit's decision in Commercial Union Insurance Co. v. Gilbane Building Co., 992 F.2d 386 (1st Cir. 1993). In Gilbane, the First Circuit held that a performance bond (with no arbitration clause) that incorporated by reference a subcontract (with no arbitration clause) that incorporated by reference a prime contract (containing an arbitration clause) created a "chain of incorporation" sufficient to bind the general contractor to arbitrate its disputes with the surety. Id. at 388. Even if the First Circuit had 
considerable variety exists among jurisdictions as to whether a subcontract or performance bond bodily incorporates all the terms of an underlying agreement or incorporates only terms related to the work to be performed. ${ }^{180}$ Courts in a few jurisdictions have distinguished between disputes arising out of the underlying contract and disputes arising out of the subcontract or performance bond and held that only the former are subject to arbitration. ${ }^{181}$ Courts in a larger number of jurisdictions have held that a reference does not bind a surety or subcontractor to the arbitration clause in the underlying agreement. ${ }^{182}$ Courts in a majority of jurisdictions have held that a reference does bind a surety or subcontractor to the arbitration clause in the under-

considered local law (it did not) it would have reached the same outcome. On similar facts, Massachusetts courts have held that subcontractors and sureties are bound by arbitration clauses contained in prime contracts which are incorporated into subcontracts or performance bonds. See Mass. Elec. Sys., Inc. v. R.W. Granger \& Sons, Inc., 594 N.E.2d 545, 546 (Mass. App. Ct. 1992) (holding that a subcontractor was bound by the arbitration clause contained in the prime contract, which was incorporated into the subcontract); Chase Commercial Corp. v. Owen, 588 N.E.2d 705, 707 (Mass. App. Ct. 1992) (holding that a guaranty and the underlying documents were "part of one transaction and were, therefore, to be read together" to incorporate the underlying agreement's arbitration clause into the guaranty); Powers Regulator Co. v. United States Fid. \& Guar. Co., 388 N.E.2d 1205, 1207 (Mass. App. Ct. 1979) (holding that a surety "agreed implicitly" to arbitration as a method of determining the contractual liability of its principal when the performance bond incorporated by reference a subcontract). Note that Powers Regulator involved the question of whether a surety was bound to the amount of liability determined by arbitration, not the question of whether the surety was bound to participate in arbitration. 388 N.E.2d at 914 . This is a slightly different question than the one decided in Gilbane and discussed in this Note.

180. Notes $181-83$ of this Note catalog for the first time all the known decisions that have considered the question of whether a subcontract or performance bond incorporates by reference the arbitration clause in an underlying agreement.

181. Gloucester City Bd. of Educ. v. Am. Arbitration Ass'n, 755 A.2d 1256, 1262-63 (N.J. Super. Ct. App. Div. 2000); Fid. \& Deposit Co. v. Parsons \& Whittemore Contractors Corp., 397 N.E.2d 380, 382 (N.Y. 1979).

182. Grundstad v. Ritt, 106 F.3d 201, 204-05 (7th Cir. 1997); Morrie Mages \& Shirlee Mages Found. v. Thrifty Corp., 916 F.2d 402, 406 n.1 (7th Cir. 1990); Cont'l Group, Inc. v. NPS Communications, Inc., 873 F.2d 613, 618 (2d Cir. 1989); Wash. Metro. Area Transit Auth. v. Norair Eng'g Corp., 553 F.2d 233, 235-36 (D.C. Cir. 1977); Interocean Shipping Co. v. Nat'l Shipping \& Trading Corp., 523 F.2d 527, 539 (2d Cir. 1975); John W. Johnson, Inc. v. Basic Constr. Co., 429 F.2d 764, 773 (D.C. Cir. 1970); Imp. Exp. Steel Corp. v. Miss. Valley Barge Line Co., 351 F.2d 503, 505-06 (2d Cir. 1965); United States Pac. Builders, Inc. v. Mitsui Trust \& Banking Co., 57 F. Supp. 2d 1018, 1019 (D. Haw. 1999); S. Leo Harmonay, Inc. v. Binks Mfg. Co., 597 F. Supp. 1014, 1024 (S.D.N.Y. 1984); Windowmaster Corp. v. B.G. Danis Co., 511 F. Supp. 157, 160 (S.D. Ohio 1981); Hartford Accident \& Indem. Co. v. Scarlett Harbor Assocs., 695 A.2d 153, 157 (Md. 1997); Sherwood Vill. Coop. A, Inc. v. Had-Ten Estates Corp., 287 N.Y.S.2d 921, 921 (N.Y. App. Div. 1968); Transamerica Ins. Co. v. Yonkers Contracting Co., 267 N.Y.S.2d 669, 671 (N.Y. Sup. Ct. 1966); Cumberland-Perry Area Vocational-Technical Sch. Auth. v. Bogar \& Bink, 396 A.2d 433, 434-35 (Pa. Super. Ct. 1978); Downingtown Area Sch. Dist. v. Int'l Fid. Ins. Co., 671 A.2d 782, 787 (Pa. Commw. Ct. 1996). 
lying agreement. ${ }^{183} \mathrm{~A}$ federal court that applies a national rule obviously will neglect these local differences.

183. Scott v. Prudential Sec., Inc., 141 F.3d 1007, 1011-12 (11th Cir. 1998); Keystone Shipping Co. v. New England Power Co., 109 F.3d 46, 52-53 (1st Cir. 1997); Asplundh Tree Expert Co. v. Bates, 71 F.3d 592, 595 (6th Cir. 1995); Gingiss Int'l, Inc. v. Bormet, 58 F.3d 328, 331-32 (7th Cir. 1995); Commercial Union Ins. Co. v. Gilbane Bldg. Co., 992 F.2d 386, 388 (1st Cir. 1993); Progressive Cas. Ins. Co. v. C.A. Reaseguradora Nacional de Venez., 991 F.2d 42, 45 (2d Cir. 1993); United States Fid. \& Guar. Co. v. West Point Constr. Co., 837 F.2d 1507, 1508 (11th Cir. 1988); Maxum Founds., Inc. v. Salus Corp., 779 F.2d 974, 980-81 (4th Cir. 1985); Exch. Mut. Ins. Co. v. Haskell Co., 742 F.2d 274, 276 (6th Cir. 1984); Compania Espanola de Petroleos v. Nereus Shipping, S.A., 527 F.2d 966, 973-74 (2d Cir. 1975); Gavlik Constr. Co. v. H.F. Campbell Co., 526 F.2d 777, 785-89 (3d Cir. 1975); J \& S Constr. Co. v. Travelers Indem. Co., 520 F.2d 809, 810 (1st Cir. 1975); J.S. \& H. Constr. Co. v. Richmond County Hosp. Auth., 473 F.2d 212, 216-17 (5th Cir. 1973); Warren Bros. Co. v. Cardi Corp., 471 F.2d 1304, 1307 n.2 (1st Cir. 1973); Uniroyal, Inc. v. A. Epstein \& Sons, Inc., 428 F.2d 523, 526-27 (7th Cir. 1970); In re S\&R Co., 984 F. Supp. 95, 98-99 (N.D.N.Y. 1997); Firemen's Ins. Co. v. Edgewater Beach Owner's Ass'n, Inc., No. 96CV 256/RV, 1996 WL 509720, at *2 (N.D. Fla. June 25, 1996); Aetna Cas. \& Sur. Co. v. L'Energia, Ltd. P'ship, No. CIV. A. 96-10098-GAO, 1996 WL 208497, at *4 (D. Mass. Mar. 4, 1996); Transamerica Premier Ins. Co. v. Collins \& Co., 735 F. Supp. 1050, 1051 (N.D. Ga. 1990); Hoffman v. Fid. \& Deposit Co., 734 F. Supp. 192, 195 (D.N.J. 1990); O\&Y Landmark Assocs. v. Nordheimer, 725 F. Supp. 578, 584 (D.D.C. 1989); Thomas O’Conner \& Co. v. Ins. Co. of N. Am., 697 F. Supp. 563, 564-65 \& 565 n.1 (D. Mass. 1988); Cianbro Corp. v. Empresa Nacional de Ingenieria, 697 F. Supp. 15, 17 (D. Me. 1988); Loyal Order of Moose, Lodge 1392 v. Int'l Fid. Ins. Co., 797 P.2d 622, 629 (Alaska 1990); Matson, Inc. v. Lamb \& Assocs. Packaging, 947 S.W.2d 324, 325 (Ark. 1997); Slaught v. Bencomo Roofing Co., 30 Cal. Rptr. 2d 618, 621-22 (Cal. Ct. App. 1994); Boys Club of San Fernando Valley, Inc. v. Fid. \& Deposit Co., 8 Cal. Rptr. 2d 587, 589-90 (Cal. Ct. App. 1992); Henderson Inv. Corp. v. Int'l Fid. Ins. Co., 575 So. 2d 770, 771-72 (Fla. Dist. Ct. App. 1991); Ins. Co. of N. Am. v. Acousti Eng'g Co., 549 So. 2d 790, 791 (Fla. Dist. Ct. App. 1989); St. Paul Fire \& Marine Ins. Co. v. Woolley/Sweeney Hotel No. 5, 545 So. 2d 958, 958-59 (Fla. Dist. Ct. App. 1989); Kidder Elec. of Fla., Inc. v. United States Fid. \& Guar. Co., 530 So. 2d 475, 477 (Fla. Dist. Ct. App. 1988); Balboa Ins. Co. v. W.G. Mills, Inc., 403 So. 2d 1149, 1150 (Fla. Dist. Ct. App. 1981); Frank J. Rooney, Inc. v. Charles W. Ackerman of Fla., Inc., 219 So. 2d 110, 112 (Fla. Dist. Ct. App. 1969); ADC Constr. Co. v. McDaniel Grading, Inc., 338 S.E.2d 733, 736-37 (Ga. Ct. App. 1985); H.R.H. Prince Ltc. Faisal M. Saud v. BatsonCook Co., 291 S.E.2d 249, 250 (Ga. Ct. App. 1982); Turner Constr. Co. v. Midwest Curtainwalls, Inc., 543 N.E.2d 249, 251-52 (Ill. App. Ct. 1989); Bolingbrook Park Dist. v. National-Ben Franklin Ins. Co., 420 N.E.2d 741, 743 (Ill. App. Ct. 1981); Russellville Steel Co. v. A \& R Excavating, Inc., 624 So. 2d 11, 13 (La. Ct. App. 1993); Kearsarge Metallurgical Corp. v. Peerless Ins. Co., 418 N.E.2d 580, 582-83 (Mass. 1981); Mass. Elec. v. R.W. Granger \& Sons, Inc., 594 N.E.2d 545, 545-46 (Mass. App. Ct. 1992); Chase Commercial Corp. v. Owen, 588 N.E.2d 705, 707 (Mass. App. Ct. 1992); Powers Regulator Co. v. United States Fid. \& Guar. Co., 388 N.E.2d 1205, 1207 (Mass. App. Ct. 1979); Travelers Indem. Co. v. Hayes Contractors, Inc., 389 N.W.2d 257, 259-60 (Minn. Ct. App. 1986); Sheffield Assembly of God Church, Inc. v. Am. Ins. Co., 870 S.W.2d 926, 931 (Mo. Ct. App. 1994); Monette v. Tinsley, 975 P.2d 361, 364 (N.M. Ct. App. 1999); City of Piqua v. Ohio Farmers Ins. Co., 617 N.E.2d 780, 782 (Ohio Ct. App. 1992); Gibbons-Grable Co. v. Gilbane Bldg. Co., 517 N.E.2d 559, 562-64 (Ohio Ct. App. 1986); Godwin v. Smith, 386 S.E.2d 464, 465-67 (S.C. Ct. App. 1989); First Baptist Church v. George A. Creed \& Son, Inc., 281 S.E.2d 121, 123 (S.C. 1981); Rashid v. Schenck Constr. Co., 438 S.E.2d 543, 547 (W. Va. 1993). 
A federal district court's 1990 decision in Hoffman v. Fidelity \& Deposit Co. ${ }^{184}$ provides a good example of how a federal court's failure to apply state law can lead to a questionable result. ${ }^{185}$ In Hoffman,

184. 734 F. Supp. 192, 195 (D.N.J. 1990). For a discussion of how the Hoffman court erroneously concluded that state law is not applicable, see supra note 110 .

185. Consider also the Seventh Circuit's 1996 decision in Grundstad v. Ritt, 106 F.3d 201 (7th Cir. 1996). That decision held that a guarantor was not bound to arbitrate a dispute arising out of an underlying noncompetition agreement. $I d$. at 205. To understand how the decision would differ under state law, it is necessary to consider the facts in some detail. Two corporations in the business of operating gambling casinos on cruise ships entered into a noncompetition agreement. Id. at 202. Under the agreement, Atlantic Associates, Inc., promised to pay a yearly sum to International Vending and Gaming, Ltd., in exchange for International Vending's promise not to compete with Atlantic in certain geographic areas. Id. The noncompetition agreement contained a broad arbitration clause. Id. After Atlantic failed to make payments due under the agreement, Ritt (as assignee of International Vending's rights) received an arbitration award of over $\$ 842,000$, which he converted to a judgment in a Massachusetts state court. Id. at 202-03. When Atlantic refused to make payment, Ritt sought to initiate an arbitration proceeding against Grundstad and Rahn, Atlantic shareholders who had guaranteed Atlantic's performance of the noncompetition agreement. Id. at 203. The guaranty, which did not contain an arbitration clause, appeared on the final page of the noncompetition agreement, immediately beneath the signatures of Ritt and Rahn as signatories to the agreement on behalf of International Vending and Atlantic Associates, respectively. Id. The agreement and the guaranty were executed the same day and made reference to each other. Id.

The Seventh Circuit held as a matter of federal law that the guaranty and the noncompetition agreement should not be read together. $I d$. at 205. The court followed a federal case from the Sixth Circuit holding that a guarantor who is not a signatory to a contract containing an arbitration clause generally is not bound by the arbitration clause. Id. at 204 (citing, with approval, Asplundh Tree Expert Co. v. Bates, 71 F.3d 592, 595 (6th Cir. 1995)). The court noted that the language of the Grundstad guaranty "does not unambiguously express Grundstad's intent to be personally bound by the arbitration clause within the [noncompetition] Agreement." $I d$. at 205. In the absence of language specifically stating that the guarantor would be bound by the arbitration clause, the court would not hold as a matter of law that he agreed to be so bound. Id.

Had the Grundstad court properly applied Illinois law (which the Seventh Circuit later acknowledged would have been applicable to this diversity case, 166 F.3d 867, 870 (7th Cir. 1999) (on rehearing after remand)), the court likely would have concluded that the guaranty should be construed with the noncompetition agreement as a single contract. The general rule in Illinois is

that in the absence of evidence of a contrary intention, where two or more instruments are executed by the same contracting parties in the course of the same transaction, the instruments will be considered together and construed with reference to one another because they are, in the eyes of the law, one contract.

Tepfer v. Deerfield Sav. \& Loan Ass'n, 454 N.E.2d 676, 679 (Ill. App. Ct. 1983) (citations omitted) (holding that mortgage note should be read together with a contemporaneously executed loan commitment document); see also Frocks v. Ziff, 74 N.E.2d 699, 703 (Ill. 1947) (holding that an option to buy realty should be construed with a lease when the option was part of the same physical document as the lease); Meeker v. Beeson, 395 N.E.2d 698, 701 (Ill. App. Ct. 1979) (holding that a purchase agreement and a leasing agreement not executed simultaneously could be read as constituting a single transaction, where the "latter document neither expressly contradicted nor superceded the prior instrument and could be reasonably interpreted as supple- 
the owner of a warehouse sought to compel the contractor's surety to participate in arbitration. ${ }^{186}$ The construction agreement between the

menting and clarifying the prior agreement"). Here, the guaranty was executed by Grundstad and Ritt on the same day that the noncompetition agreement was executed by Grundstad and Ritt on behalf of International Vending and Atlantic Associates. Grundstad, 106 F.3d at 202. The guaranty and noncompetition agreement not only made reference to each other, they were joined together as part of a single document. $I d$. at 203. Both agreements served the purpose of “"facilitat[ing] Ritt's departure from Atlantic [Associates]." Id. at 202. Because the guaranty and the noncompetition agreement were executed by the same parties, for the same purpose, at the same time, a court applying Illinois law likely would conclude that the agreements constitute a single transaction.

It might be argued that a guaranty and its underlying agreement are never executed for "the same purpose," since the purpose of the former is to guarantee the obligations of the latter. But there is precedent in Illinois for the proposition that a guaranty and the underlying agreement should be construed together. Fisher v. United States Fid. \& Guar. Co., 39 N.E.2d 67, 6871 (Ill. App. Ct. 1942); McComb v. Meade, 256 Ill. App. 128, 137-40 (Ill. App. Ct. 1930) (holding that a note executed by a bank trustee and a guaranty and covenant of the bank not to sue, executed as part of same transaction, were required to be construed as one contract); Colbert v. Holland Furnace Co., 241 Ill. App. 583, 586-87 (Ill. App. Ct. 1926) (holding that a bond guaranteeing a project against defects must be considered a part of the construction contract); Webbe v. Romona Oolitic Stone Co., 58 Ill. App. 222, 225 (Ill. App. Ct. 1894) (holding that a guaranty should be read with reference to the memorandum of settlement preceding it). Modern decisions in other states also have interpreted a guaranty as part of the same contract as other contemporaneously executed agreements. E.g., Spottiswoode v. Levine, 730 A.2d 166, 173 (Me. 1999) ("Since the guaranty and commitment letters were "executed at the same time, by the same contracting parties, for the same purpose, and in the course of the same transaction,' we consider and construe them together as one contract or instrument."). These cases likely would be persuasive to a court ascertaining Illinois law.

Moreover, Illinois courts have been quite willing to require nonsignatories to arbitrate disputes. In Illinois, arbitration is a favored method of settling disputes. Turner Constr. Co. v. Midwest Curtainwalls, Inc., 543 N.E.2d 249, 252 (Ill. App. Ct. 1989); Kostakos v. KSN Joint Venture No. 1, 491 N.E.2d 1322, 1325 (Ill. App. Ct. 1986). The Appellate Court of Illinois has held that sureties as a matter of law agree to arbitrate disputes when their bond incorporates by reference an underlying agreement, even if the reference says nothing about whether the rights and remedies of the parties to the underlying agreement are available to the parties to the bond. Bolingbrook Park Dist. v. National-Ben Franklin Ins. Co., 420 N.E. 2d 741, 743 (Ill. App. Ct. 1981) (noting that the bond stated that " Contractor has by written agreement ... entered into a contract with Owner... which contract is by reference made a part hereof, and is hereinafter referred to as the Contract"'); see also Turner, 543 N.E.2d at 252 (holding that a general contractor was obliged to arbitrate disputes with a subcontractor, despite the absence of an arbitration clause in the subcontract, when the subcontract incorporated by reference a general contract containing an arbitration clause). Although the incorporation cases would not directly dictate the outcome in Grundstad (since the Grundstad guaranty did not incorporate the underlying agreement), the cases evince a policy in Illinois of construing guaranties broadly to effectuate arbitration agreements. A court applying Illinois law likely would do the same.

Had the Grundstad court properly considered basic Illinois contract principles, developments in other states, and the Illinois cases, it likely would have concluded that the guaranty and the noncompetition agreement were part of the same contract and that the guarantor was bound to submit to arbitration. Because the Seventh Circuit failed to apply state law, it reached the opposite outcome.

186. Hoffman, 734 F. Supp. at 193. 
owner and the contractor contained an arbitration clause. ${ }^{187}$ As surety, Fidelity had executed and delivered to the owner a performance bond that incorporated the construction agreement by reference. ${ }^{188}$ The bond did not include an arbitration clause. Claiming that the contractor's workmanship was faulty, the owner instigated an arbitration against the contractor and asked the district court to compel the surety to participate. The Hoffman court ignored state law and followed inapposite federal decisions from other circuits. Had the court correctly applied New Jersey contract law, ${ }^{189}$ it might not have ordered Fidelity to proceed to arbitration.

New Jersey law provides no specific answer to the question of whether a surety has agreed to submit to arbitration by referencing a construction contract containing an arbitration clause. In fact, the New Jersey Supreme Court considered-and explicitly reservedthat exact question three years before Hoffman..$^{190}$ A later New Jersey case (decided one year before Hoffman) lent support to the proposi-

187. Id. at 193. Under the construction agreement, “'[a]ll claims, disputes and other matters in question between the parties to this Agreement, arising out of or related to this Agreement or the breach thereof, shall be decided by arbitration or litigation, at the election of the owner."' Id.

188. Id. ("“Contractor has by written agreement ... entered into a contract with Owner for construction of a Building Addition ... which contract is by reference made a part hereof, and is hereinafter referred to as the Contract."').

189. The relevant law comes from New Jersey. Federal district courts must apply the conflicts law of the states in which they sit. Klaxon Co. v. Stentor Elec. Mfg. Co., 313 U.S. 487, 496 (1941). Under New Jersey conflicts law, the validity of a contract for the rendition of services and the rights created thereby are determined, in the absence of an effective choice of law by the parties, by the local law of the state where the contract requires that the services, or a major portion of the services, be rendered, unless, with respect to the particular issue, some other state has a more significant relationship to the transaction and the parties, in which event the local law of the other state will be applied. McCabe v. Great Pac. Century Co., 537 A.2d 303, 304-06 (N.J. Super. Ct. App. Div. 1989) (holding that New Jersey law applied to a construction contract when the building would be built in New Jersey). In Hoffman, the contract was to be performed in New Jersey and arbitration was to occur in New Jersey. 734 F. Supp. at 193, 195. There was no evidence of a choice-of-law clause, nor was there evidence that another state had a relationship to the transaction. Therefore, New Jersey should have provided the law relevant to the rights and liabilities of the parties under the construction agreement.

190. Raymond Int'l Builders, Inc. v. First Indem. of Am. Ins. Co., 516 A.2d 620, 623 (1986) (following citations to cases on both sides of the question, the court stated that it "need not reach this issue" and proceeded to decide the case on other grounds not important to this Note); see also Seaboard Sur. Co. v. Bd. of Chosen Freeholders, 537 A.2d 310, 314 (N.J. Super. Ct. App. Div. 1988) (observing that in Raymond the New Jersey Supreme Court "did not deem it necessary to decide whether, in those circumstances, the surety is subject to joinder by the creditor in an arbitration proceeding initially brought against the principal pursuant to the creditorprincipal contract"). There is still no firm answer to that question under New Jersey law. 
tion that a surety is free to ignore arbitration proceedings. ${ }^{191}$ (The federal court in Hoffman did not cite either New Jersey case, nor did it acknowledge that New Jersey law is unsettled on this point.) ${ }^{192}$

Even though New Jersey law provides no formal interpretive rule to resolve the dispute in Hoffman, basic New Jersey contract principles suggest that the district court reached an improper result. In New Jersey, a contract is ambiguous where the terms of the contract are reasonably susceptible to more than one interpretation, or where the contract language can support reasonable differences of opinion as to the obligations undertaken. ${ }^{193}$ Here, the incorporation by reference was susceptible to more than one interpretation. The reference could have meant that the surety agreed that it would possess the exact rights and submit to the exact remedies of its principal, including arbitration. The reference also could have meant that the surety guaranteed the scope, quality, character, and manner of the nonsignatory's performance, but did not submit to the principal's procedures for dispute resolution. Language in the construction agreement supported the latter interpretation. The construction agreement-never signed by the surety-provided that disputes "between the parties to this Agreement" were subject to arbitration. ${ }^{194}$ Moreover, the performance bond did not contain an arbitration clause. ${ }^{195}$ Had the parties intended to subject the surety to arbitration, the performance bond would be the most logical place to include an arbitration clause. Indeed, most standard form performance bonds contain provisions for remedies, such as forum-selection or choice-of-law clauses. ${ }^{196}$ Because the construction agreement, as incorporated into

191. Seaboard, 537 A.2d at 314 (holding that a surety may submit voluntarily to arbitration or ignore arbitration, although if the surety takes the latter course "it will be bound by the arbitration award against the principal if it was adequately noticed of the arbitration proceeding, afforded the time and information necessary to prepare for arbitration and kept informed at every stage of the arbitration proceeding").

192. When state law is unsettled, federal courts have discretion to make use of state certification procedures to allow state courts to develop their own law. Lehman Bros. v. Schein, 416 U.S. 386, 389-91 (1974). But New Jersey has no certification procedure. RTC Mortgage Trust 1994 N-1 v. Fid. Nat'l Title Ins. Co., 981 F. Supp. 334, 352 n.18 (D.N.J. 1997).

193. Camden \& Trenton Ry. Co. v. Adams, 51 A. 24, 25 (N.J. Ch. 1902) ("If the contract as written is so ambiguous that its expressions are susceptible of more than one meaning, evidence of the accompanying negotiations is admitted in order to point out which meaning was within the intent of the parties.").

194. Hoffman v. Fid. \& Deposit Co., 734 F. Supp. 192, 193 (D.N.J. 1990) (emphasis added).

195. Id.

196. See, e.g., Am. Inst. of Architects, supra note 82, at 2 ("Any proceeding, legal or equitable, under this Bond may be instituted in any court of competent jurisdiction in the location in 
the performance bond, was susceptible to more than one interpretation, the agreement was ambiguous as a matter of New Jersey law.

In New Jersey, if the language of a contract is ambiguous, evidence may be admitted as to the intent of the parties, and the determination of the parties' intent is a question of fact (for a jury) ${ }^{197}$ In light of the agreement's ambiguity, the district court should have attempted to ascertain the intention of the parties through parol evidence of the accompanying negotiations and customs and usage in the construction bond industry. A proper application of New Jersey law should have caused the district court to conduct a full-blown evidentiary hearing to determine the intentions of the parties to the performance bond. In New Jersey, formal interpretative rules (like the per se rule followed by the Hoffman court) are readily subordinated to the policy of ascertaining and effectuating the contemplation or common intention of parties. ${ }^{198}$ Had the Hoffman court considered New Jersey law-as a New Jersey court likely would have done-it would not have granted summary judgment in favor of arbitration.

Cases like Hoffman, in which the result depended in part on the forum, encourage litigants to seek the forum most likely to apply a favorable law. And, as the Supreme Court noted in Erie Railroad Co. v. Tompkins, "mischievous results" ensue when federal courts apply "general law" different from the law in the state courts. ${ }^{199}$

which the work or part of the work is located ...."); Am. Inst. of Architects, Performance Bond, supra note 86, at 2 (specifying that any "suit" under the bond be instituted within certain time limits). The use of the noun "suit" in Document A311/CM suggests that adjudication—not arbitration-is the prescribed method of dispute resolution.

197. Michaels v. Brookchester, Inc., 140 A.2d 199, 204 (N.J. 1958); Anthony L. Petters Diner, Inc. v. Stellakis, 493 A.2d 1261, 1270 (N.J. Super. Ct. App. Div. 1985) (holding that where a contract term's meaning is uncertain or ambiguous, its meaning will depend upon parol evidence admitted in aid of interpretation, and the meaning of the doubtful provisions will be a question of fact); Camden, $51 \mathrm{~A}$. at 25-26.

198. Ace Stone, Inc. v. Township of Wayne, 221 A.2d 515, 520 (N.J. 1966) (remanding a dispute over an ambiguous contract "to enable the parties to introduce such oral and documentary evidence as may be available and relevant in aid of interpretation").

199. The Supreme Court's description in Erie of the "mischievous results" of the Swift v. Tyson doctrine describes the results of federal courts' failure to apply state law to the threshold inquiry in the Arbitration Act context:

Swift v. Tyson .... made rights enjoyed under the unwritten "general law" vary according to whether enforcement was sought in the state or in the federal court .... In attempting to promote uniformity of law throughout the United States, the doctrine had prevented uniformity in the administration of the law of the State.

304 U.S. 64, 74-75 (1938).

Critics of the application of state law to the threshold question might argue that the Supreme Court's teaching in Perry encourages horizontal forum shopping, even while it dis- 


\section{CONCLUSION}

When Congress enacted the Federal Arbitration Act in 1925, the Act was understood to be a procedural statute that supplementednot supplanted-state contract law. During the last thirty years, the Supreme Court has recast the Act as a national regulatory statute that leaves little role for state law.

The Court has permitted only one exception to this nationalist trend. In Perry v. Thomas and subsequent decisions, the Court instructed lower courts to apply general state contract law to questions concerning the validity, revocability, and enforceability of arbitration agreements. But this federalist thread has gone virtually unnoticed in the crazy quilt of Arbitration Act jurisprudence. Because of the complexity of the Supreme Court's arbitration decisions, courts have neglected to observe generally applicable state contract rules. They have continued to follow federal court decisions. As a result, the benefits of federalism have not been realized in the arbitration context. Parties who bargained against the background of state contract law are finding themselves bound by foreign rules of law. Parties are being forced to arbitrate disputes they never intended to arbitrate. States' prerogative to enact laws for the protection of their citizens is threatened. And vertical forum shopping is encouraged, as litigants seek favorable rules of law.

\footnotetext{
courages vertical forum shopping. A litigant seeking to avoid arbitration might seek a forum state where the local contract principles are more favorable to its defenses. But horizontal forum shopping is not likely to be a problem and, in any event, it is likely to be less of a problem than vertical forum shopping. This is so for two reasons, one theoretical, one practical. First, horizontal forum shopping is less troublesome than vertical forum shopping. Horizontal forum shopping is an important aspect of America's federal system. As the Supreme Court noted in Klaxon Co. v. Stentor Electronic Manufacturing Co., "[w]hatever lack of uniformity this may produce between federal courts in different states is attributable to our federal system, which leaves to a state, within the limits permitted by the Constitution, the right to pursue local policies diverging from those of its neighbors." 313 U.S. 487, 496 (1941). Second, as a practical matter, horizontal forum shopping is unlikely to occur. Standard form agreements almost invariably contain a choice-of-law clause stating which state's law will govern the interpretation of the document. See, e.g., Am. Inst. of Architects, General Conditions, supra note 86, § 13.1.1 ("The Contract shall be governed by the law of the place where the Project is located."). Moreover, a plaintiff's choice of forum will be limited by the constitutional requirement that the forum have at least some minimal contacts with the parties and the litigation before it may apply its law. See Allstate Ins. Co. v. Hague, 449 U.S. 302, 312-13 (1981) (“[F]or a State's substantive law to be selected in a constitutionally permissible manner, that State must have a significant contact or significant aggregation of contacts, creating state interests, such that choice of its law is neither arbitrary nor fundamentally unfair."). Most litigants therefore face little, if any, choice as between different states' contract laws.
} 
Only when lawyers bring to courts' attention the full significance of Perry and its federalist progeny (such as First Options of Chicago, Inc. v. Kaplan) will its benefits be realized. Arbitration is supposed to be purely a matter of contract, a process that cannot be compelled unless a party intended to forego a judicial forum for the resolution of disputes. The sedulous application of state contract principles, as mandated by recent Supreme Court decisions, remains the best way to protect parties against the unintended waiver of their right to judicial redress. 